\title{
Leverage, volatile future earnings growth and expected stock returns
}

\author{
Jamie Alcock ${ }^{\mathrm{A}}$, Eva Steiner ${ }^{\mathrm{B}}$ and Kelvin Jui Keng Tan ${ }^{\mathrm{C}}$

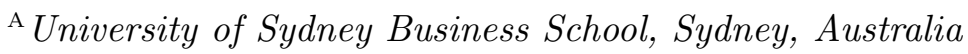 \\ ${ }^{\mathrm{B}}$ University of Cambridge, Cambridge, United Kingdom \\ ${ }^{\mathrm{C}}$ University of Queensland Business School, Queensland, Australia
}

\begin{abstract}
We provide theory and evidence to complement Choi's [RFS, 2013] important new insights on the returns to equity in 'value' firms. We show that higher future earnings growth ameliorates the value-reducing effect of leverage and, because the market for earnings is incomplete, reduces the earnings-risk sensitivity of the default option. Ceteris paribus, a levered firm with low (high) earnings growth is more sensitive to the first (second) of these effects thus generating higher (lower) expected returns. We demonstrate this by modelling equity as an Asian-style call option on net earnings and find significant empirical support for our hypotheses.
\end{abstract}

Key words: Corporate leverage, default risk, earnings risk, earnings growth, value vs growth, stochastic earnings valuation model.

JEL Classification: G12, G14

\footnotetext{
* We thank Andrew Patton, Tom Smith, Stephen Satchell, Stephen Schaefer, Bruce Grundy, Stephen Penman, Michael Roberts, Chris Rogers, Terry Walter, K.C. John Wei, David Johnstone, Kevin Aretz, Jay J. Choi, Robert Faff and Amir Yaron for helpful comments and suggestions. We also thank the participants of the University of Sydney Finance Seminar 2014, the University of Queensland Business School Finance Seminar 2013, and the Cambridge-Princeton Finance Symposium 2013, for their constructive comments and suggestions. The usual disclaimer applies.
} 


\section{Introduction}

The positive return premium delivered by firms with low growth opportunities relative to firms with high growth opportunities is well established empirically (Fama and French, 1992, 1993; Rosenberg, Reid, and Lanstein, 1985; Stattman, 1980), but its fundamental economic drivers remain incompletely understood. Some authors suggest a rational, risk-based explanations for this premium (Aretz, Bartram, and Pope, 2010; Fama and French, 1996; Garcia-Feijoo and Jorgensen, 2010; Vassalou, 2003). An alternative stream of research suggests that the value premium reflects mispricing based on cognitive biases (Daniel and Titman, 1997; Lakonishok, Shleifer, and Vishny, 1994). A more recent stream of research finds that leverage plays a considerable role in either a firm-level or portfolio-level 'value' premium (Choi, 2013; Garcia-Feijoo and Jorgensen, 2010; Garlappi and Yan, 2011; Gomes and Schmid, 2010; Obreja, 2013) as does asset growth (Cooper, Gulen, and Schill, 2008). More recently, Choi (2013) provides empirical evidence that the interaction between asset risk and financial leverage explains a significant proportion of the equity risk dynamics of value versus growth stocks.

We argue that the positive return premium to 'value' firms compared to 'growth' firms is, at least in part, a logical confluence of two effects of corporate leverage; namely that corporate leverage reduces the residual claim of equity on corporate earnings, and corporate leverage increases the relative value of earnings risk in the default option held by equity owners. Both of these effects respond to higher expected earnings growth. ${ }^{1}$ Higher future earnings growth ameliorates the value-reducing effect of leverage by increasing the flow of earnings to equity holders. The default option for firms with higher corporate leverage is less sensitive to earnings risk. Ul-

\footnotetext{
1 Many studies that suggest explanations for this return premium focus on the asset value component of growth opportunities, captured in the book-to-market ratio, but growth opportunities also generate potential future earnings growth. The actual rate of future earnings growth is volatile, as it varies with business cycle fluctuations and managerial decisions. Fama and French (2014) also highlight the role of corporate earnings in the context of generating a positive return differential on low growth firms in the context of the dividend discount model. Our work explicitly accounts for the effects of risk in future earnings growth
} 
timately, this is because the earnings market is incomplete; the primary way to gain exposure to a firm's earnings process is by investing in the firm's equity. Our argument provides a novel insight into the economic drivers of the results of (Choi, 2013) and related works (Ai and Kiku, 2013; Cooper, Gulen, and Schill, 2008; Garlappi and Yan, 2011)

We explore the relationships between leverage, growth opportunities and the price of equity using a stochastic earnings valuation model of equity. ${ }^{2}$ This model views the equity claim of a levered firm as an Asian-style call option on net earnings. We show that firms with low growth opportunities are more sensitive to the value-reducing effects of leverage, relative to firms with high growth opportunities, suggesting a rational explanation for an expected return premium on low growth firms. ${ }^{3}$

Choi (2013) and related papers (Cooper, Gulen, and Schill, 2008; Trigeorgis and Lambertides, 2014) finds that value firms are more sensitive to economic conditions than growth firms. Our work provides additional insight into the drivers of this differential sensitivity across value and growth firms to economic conditions. Specifically, we develop and empirically test two main hypotheses. First, the expectation of future earnings growth attenuates the effect of leverage on the price of equity. In a levered firm, a share of accumulated earnings is distributed to debt holders, with this share increasing in leverage. For a solvent firm with a given level of leverage, future earnings growth produces earnings that primarily accrue to equity holders as residual claimants. Therefore, ceteris paribus, an increase in leverage reduces the price of equity and thus increases the expected return to equity of a firm with low expected future earnings growth by more than that of a firm with high expected future earnings growth. We hypothesise that the increased sensitivity of low-growth

\footnotetext{
2 Studies that explore valuation models similar to ours include Alcock, Mollee, and Wood (2011); Apabhai, Georgikopoulos, Hasnip, Jamie, and Kim (1999); Epstein, Mayor, Schönbucher, Whalley, and Wilmott (1998) and $\mathrm{Li}$ (2003).

3 Our model is general but can be extended to demonstrate that small firms attract a return premium relative to large firms.
} 
firms to the effects of leverage on the price of equity commands an expected return premium relative to high-growth firms.

Our second hypothesis is that the expectation of future earnings growth affects the sensitivity of the price of equity to the volatility of future earnings growth. The price of equity of low-growth firms is more sensitive to future earnings growth volatility than that of high-growth firms, as the potential of future earnings growth implied in a volatile earnings growth process is more valuable in a low-growth firm, whose price of equity is more sensitive to the effects of leverage. We hypothesise that this differential sensitivity increases the price of equity for low-growth firms compared to the price of equity for high-growth firms, reducing relative expected returns. We find statistically and economically significant empirical evidence to support both of these hypotheses.

A number of studies suggest that low-growth (value) firms command a return premium relative to high-growth (growth) firms because the former are more sensitive to (macroeconomic) volatility risks (Ai and Kiku, 2013; Bansal, Dittmar, and Kiku, 2009; Bansal, Dittmar, and Lundblad, 2005; Barinov, 2013; Hansen, Heaton, and Li, 2008; Lettau and Wachter, 2007). Our findings generally concur with a differential sensitivity to volatility risks as a driver of the return premium. However, in terms of the direction of the impact of volatility on stock returns, our results are more consistent with Johnson (2004) who argues that firm volatility generally increases the value of equity. We find that the positive response in the price of equity to firm volatility is a function of the firm's growth potential: low-growth firms being more sensitive to the impact of earnings growth volatility than high-growth firms. We also find that low-growth (value) firms are more sensitive to the impact of leverage than high-growth (growth) firms. The upside-only potential implied in a risky earnings process is more valuable in a low-growth firm, whose equity is more sensitive to the value-reducing effects of leverage. Ceteris paribus, a levered firm 
with low growth attracts a lower price, and hence higher expected returns, than a high-growth firm.

In addition, our findings provide insight into the channels through which volatility risks impact upon expected stock returns. The literature to date largely considers the influence of macroeconomic, or systematic, risks (Bansal, Kiku, Shaliastovich, and Yaron, 2012; Bansal, Kiku, and Yaron, 2007; Bansal and Yaron, 2004; Drechsler and Yaron, 2011) and firm-specific volatility risks (Ang, Hodrick, Xing, and Zhang, 2006, 2009; Avramov, Cederburg, and Hore, 2012; Bali, Cakici, Yan, and Zhang, 2005; Barinov, 2013; Barron, Stanford and Yu, 2009; Diether, Malloy, and Scherbina, 2002; Goyal and Santa-Clara, 2003; Johnson, 2004; Lehmann, 1990; Malkiel and Xu, 1997, 2002) on stock returns in isolation from each other. This separation makes it difficult to identify the canonical effects of these two sources of uncertainty. We empirically account for both the systematic and idiosyncratic components of risk surrounding future earnings growth. Our approach allows us to clarify how systematic and idiosyncratic factors are reflected in the total volatility of the firm's earnings process as a central driver of value.

Furthermore, we trace how the effects of systematic and idiosyncratic volatility filter through to expected stock returns for low- and high-growth firms. We find that both systematic and idiosyncratic future earnings growth volatility increase the price of equity for a levered firm. Moreover, we find that low-growth firms are significantly more sensitive to both types of volatility than high-growth firms. Our evidence suggests that the positive contribution of volatility to the price of equity for low-growth firms is primarily driven by idiosyncratic volatility, while the higher sensitivity of low-growth firms to systematic volatility increases expected returns relative to high-growth firms, again on balance producing a positive return premium for low-growth firms. 


\section{Hypothesis development}

Consider a firm that generates net earnings, $E_{t}$, continuously through time that grow at a constant rate $\bar{g}$. These earnings can be modelled using the ordinary differential equation

$$
d E_{t}=\bar{g} E_{t} d t
$$

Risky earnings growth will also incorporate a noise component. If these noisy shocks are independently normally distributed, then $\overline{g_{t}}=g+\sigma \Psi_{t}$, where $\Psi_{t}$ is a white noise process. The differential equation for earnings is then given by:

$$
d E_{t}=g E_{t} d t+\sigma E_{t} d W_{t}
$$

where $W_{t}$ is a standard Wiener process. ${ }^{4}$ The earnings of a firm with finite life $T$ are continuously deposited into a risk-free bank account whose current balance, $A_{t}$, is given by:

$$
A_{t}=\int_{0}^{t} e^{r_{f}(t-s)} E_{s} d s
$$

The earnings of the firm are generated by assets purchased at time 0 with the proceeds of a single debt-issuance. These assets are assumed to be fully depreciated over the life of the firm, so that the residual value of these assets at time $T$ is zero. For simplicity, we assume that this debt is a $T$-year zero-coupon bond, issued at par $(D)$.

Building on the contingent claims approach (Black and Scholes, 1972), equity is modelled as a call option on the balance of this bank account. As the balance of this bank account is the integral of the firm's earnings, equity is an Asian-style call

\footnotetext{
4 The realised earnings of most firms cannot be guaranteed to be a strictly positive process. Valuing firms with periods of negative earnings in any of the current valuation frameworks requires some restrictive assumptions be placed on the earnings process. For example, the DCF can value firms with negative earnings only if the timing and expectation of any negative earnings are anticipated. For the model described above, if the true earnings process, $E_{t}$, is bounded from below by $-\kappa$ then one can define $\tilde{E}_{t}=E_{t}+\kappa$ to be a strictly positive earnings process governed by a GBM (2). This is less stringent than requiring that the timing and value of any negative earnings are anticipated. Rather, we only require that the minimum of any negative earnings is anticipated.
} 
option on the firm's net earnings, struck at the face value of debt. ${ }^{5}$ The variation in the price of equity, $d P$, is then given by:

$$
d P=\frac{\partial P}{\partial A} d A+\frac{\partial P}{\partial E} d E+\frac{\partial P}{\partial t} d t+\frac{1}{2} \frac{\partial^{2} P}{\partial E^{2}}(d E)^{2}
$$

where $d A=\left(E+r_{f} A\right) d t$ and $(d E)^{2}=\sigma^{2} d t$. As earnings are not hedgeable, we cannot derive the pricing equation in a risk-neutral framework, and employ a general equilibrium setting instead. Standard equilibrium arguments give the price of equity in terms of the partial differential equation:

$$
\frac{\partial P}{\partial t}+\left(E+r_{f} A\right) \frac{\partial P}{\partial A}+g E \frac{\partial P}{\partial E}+\frac{1}{2} \sigma^{2} E^{2} \frac{\partial^{2} P}{\partial E^{2}}-\left(r_{f}+\lambda\right) P=0
$$

where $\lambda$ represents the market price of earnings risk. Importantly, the pricing equation (4) contains the drift parameter $g$. This is a direct consequence of the market for earnings being incomplete. In contrast to many contingent claim models of equity, expected future earnings growth does impact on the price of equity, and affects the sensitivity of equity value to leverage and earnings risk.

In the presence of debt, $D$, the boundary conditions are:

$$
\begin{gathered}
P(E, A, T)=\max (A-D, 0), \\
\lim _{E \rightarrow \infty} \frac{\partial^{2} P}{\partial E^{2}}=0, \\
\frac{\partial P}{\partial t}+r_{f} A \frac{\partial P}{\partial A}-r_{f} P=0, \quad \text { on } E=0, \\
\lim _{A \rightarrow \infty} P(E, A, t) \approx A-D .
\end{gathered}
$$

where (6) and (8) limit the asymptotic growth of $P$ with respect to $E$ and $A$.

This model captures several well-known characteristics of capital management.

$\overline{5}$ Key papers on the pricing of Asian-style options include Henderson and Wojakowski (2002); Nielsen and Sandmann (2003); Rogers and Shi (1995). 
First, for a given level of earnings the level of leverage determines the share of earnings that is distributed to debt holders and thus transferred away from equity holders as residual claimants. This share increases in leverage. Therefore, the immediate effect of increasing leverage is to reduce the price of equity as a residual claim on earnings. ${ }^{6}$ Second, leverage increases the value (to equity holders) of the volatility in future earnings growth. Leverage introduces default risk, and the option to default limits the downside of equity as a call on accumulated earnings. From the perspective of equity holders, the potential of future earnings growth embedded in a volatile earnings growth process becomes upside-only. For a given level of leverage, volatility offers the possibility of positive future earnings growth that accrues primarily to equity holders, even when expected future earnings growth is low. Uncertainty in the earnings growth process increases the price of equity.

The general equilibrium model in Equation (4) also captures the implications of an incomplete market for earnings. The traditional contingent claims approach (Black and Scholes, 1972) prices equity as a call option on the firm's assets, valued by reference to a replicating portfolio that perfectly hedges the risks of exposure to the firm's equity through constructing an exactly offsetting position directly in the underlying assets. The model prices equity as a call option on the firm's earnings. However, the primary way to gain exposure to the firm's earnings is through investing in the firm's equity. The possibility to hedge the risks of exposure to the firm's earnings through alternative securities other than the firm's equity is limited. This limitation to constructing an exactly offsetting position in the underlying has two major implications. The market price of earnings risk, captured in the parameter $\lambda$, enters the model in addition to the risk-free rate, as investors require compensation for earnings risk in addition to the risk-free rate. On the other hand, expected future earnings growth has a significant impact on the price of equity, as the parameter $g$

\footnotetext{
6 Our argument does not imply that firms should not use leverage. Firms may use leverage and employ the borrowed funds to invest in assets in the expectation that the return on equity increases so long as the marginal return on these assets exceeds the marginal cost of debt. Rather, we study the marginal effect of leverage on an all else equal basis.
} 
cannot be eliminated from the pricing formula. As a result, the model generates a set of implications for the interrelationships between expected future earnings growth, leverage, the volatility of future earnings growth, and the price of equity.

We illustrate these interrelationships between expected future earnings growth, leverage, the volatility of future earnings growth, and the price of equity using numerical solutions to the stochastic earnings valuation model (4). Figure 1(a) shows that the the price of equity decreases in leverage. Increasing levels of leverage increasingly transfer the benefits of earnings from equity holders, as residual claimants, to debt holders. Figure 1(b) shows that positive earnings growth mitigates the effect of leverage on the price of equity, as earnings growth generates future earnings benefits that accrue primarily to equity holders. In addition, this figure illustrates that future earnings growth volatility helps counteract the effect of leverage on the price of equity. The bounded downside of equity as a call option on the value of the firm's earnings, which drives the upside potential embedded in uncertain future earnings growth, supports the price of equity in the presence of debt. Earnings growth volatility therefore complements expected earnings growth in that it provides a potential value gain that primarily benefits equity holders as residual claimants on the earnings of the firm for a given level of leverage.

[Insert Figure 1 about here.]

Figure 2(a) illustrates the differences in the sensitivity of the price for equity of high and low earnings growth firms to leverage (presented as the ratio of prices of equity for high growth firms to prices of equity for low growth firms). For low leverage, the ratio of the price of equity of a high volatility firm to the price of equity of a low volatility firm is low and largely insensitive to the rate of earnings growth. The shielding effects of expected earnings growth and the potential for earnings growth implied in a volatile earnings process add little value for equity holders. Consequently, the prices of equity for high and low growth and volatility 
firms converge. However, when leverage is high, then the ratio between the price of equity for a high volatility firm and a low volatility firm is significantly higher, especially when earnings growth is low. This observation suggests that for high levels of leverage, earnings growth volatility becomes increasingly more valuable for equity holders - particularly as earnings growth itself decreases - increasing the relative price of equity of a high volatility firm as compared to a low volatility firm. Furthermore, the price ratio decreases in earnings growth, consistent with the observation that earnings growth and earnings growth volatility are complements in the mitigation of the effect of leverage on the price of equity. These relationships imply that the price of equity of a low growth firm is more sensitive to changes in leverage than that of a high growth firm.

\section{[Insert Figure 2 about here.]}

Figure 2(b) shows a complementary perspective on the relative value of earnings growth volatility by comparing the price of equity for high and low leverage firms. When earnings growth volatility is high, then the ratio of the prices of equity for low and high leverage firms is low. High earnings growth volatility mitigates the reduction in the value of the residual equity claim arising from the obligation to share the benefits of earnings with debt holders, reducing the incremental compensation required by equity holders for sharing the benefits of earnings with debt holders. Further, the price ratio is slightly decreasing in earnings growth, reflecting that earnings growth and volatility are complements in mitigating the effect of leverage on the price of equity. These observations suggest that earnings growth volatility is more valuable in a value firm, whose equity, as a residual claim, is more exposed to the detrimental effects of leverage, than in a growth firm, whose price of equity is shielded from these effects by positive expected earnings growth.

The model in Equation (4) gives rise to two empirically testable hypotheses. First, the increased exposure of low-growth firms to the effects of leverage requires 
incremental compensation in terms of higher expected returns for firms with low expected future earnings growth relative to firms with high expected future earnings growth.

H1: Expected stock returns for low-growth firms are more positively related to leverage than for high-growth firms.

Second, earnings growth volatility represents upside-only potential for earnings growth that primarily accrues to equity holders, which increases the price of equity for a levered firm, thus reducing expected stock returns. Low-growth firms are relatively more sensitive to the effects of earnings growth volatility than high-growth firms, reducing relative expected returns. Therefore, we expect that an interaction term between an indicator for low-growth firms and future earnings growth volatility is significant in determining expected stock returns, and carries a negative sign.

H2: Expected stock returns for low-growth firms are more negatively related to future earnings growth volatility than for high-growth firms.

However, leverage has a first-order negative effect on the price of equity, while earnings growth volatility, as a higher-order term in the earnings process that governs the value function, has a second-order positive effect on the price of equity. Therefore, we expect that the higher sensitivity of low-growth firms to the effects of leverage (positive impact on expected stock returns) dominates the higher sensitivity of lowgrowth firms to future earnings growth volatility (negative impact on expected stock returns). On balance therefore, in economic terms, we anticipate a net positive return premium on low-growth firms relative to high-growth firms. 


\begin{tabular}{lccc}
\hline & Price of Equity & Expected Returns $\left[P_{t+1}-P_{t}\right] / P_{t}$ for \\
\cline { 3 - 3 } & $\left(P_{t}\right)$ & All Firms & Low Earnings Growth Firms \\
\hline Higher Leverage & Lower & Higher & Higher (H1) \\
Higher Earnings Growth Volatility & Higher & Lower & Lower $(\mathrm{H} 2)$ \\
\hline \hline
\end{tabular}

The longer the term-to-maturity of the debt of a growing firm, the less likely the firm is to default on a zero-coupon bond. Nevertheless, the main insights and hypotheses are not dependent upon the term-to-maturity of the firms debt. The same value drivers act in the similar way with longer term debt, although with decreasing effect. As we illustrate in Figure 3, we expect our hypotheses to hold for firms with different debt maturities; that is, our hypotheses are not dependent upon firms having any particular finite debt maturity.

[Insert Figure 3 about here.]

Several authors provide evidence that smaller firms exhibit significantly greater earnings risk than larger firms (Ciftci and Cready, 2011; Kothari, Laguerre, and Leone, 2002). That is, size is inversely proportional to earnings growth volatility. We can further extend our model by incorporating this empirical characteristic. To do this, we substitute $1 / \log ($ size $)$ for $\sigma_{t}$ in (4). Doing this generates a similar set of hypotheses as $\mathrm{H} 1$ and $\mathrm{H} 2$, except for small firms rather than low growth firms. That is, adapting our model in this manner generates a prediction that smaller firms will attract an additional return premium relative to large firms. Similarly, a small firm*low growth interaction term will also be significant in firm-level returns. We empirically confirm both of these predictions in Appendix A (see Table A.1). 


\section{Data and method}

\subsection{Data set and variable measurement}

The initial sample of all NYSE, Amex and Nasdaq traded firms on Compustat during 1962-2013 has 216,119 firm-year observations. After excluding financial firms (SIC Codes 6000-6999), merging the sample with CRSP stock returns and discarding observations with missing information, the final sample has 63,959 firm-year observations.

We measure firm returns using the monthly holding period return $(R E T)$ from Compustat, that accounts for dividends and stock splits. We calculate annual returns from July $t$ to June $t+1$ to allow sufficient time for accounting information to be factored into prices (Fama and French, 1992).

We measure expected future earnings growth as the earnings-to-price ratio of the firm. We measure total future earnings growth volatility in two different ways. First, we measure actual future earnings growth volatility as the standard deviation of the first difference in earnings, calculated between the end of year $t$ and $t+3$. Second, we generate a conditional expectation of total future earnings growth volatility, using a firm-level autoregressive model. We forecast expected future earnings growth volatility as a function of past earnings growth volatility, as follows:

$$
\text { Egvol }_{i t}=\alpha_{i}+\beta_{1} \text { Egvol }_{i, t-1}+\epsilon_{i t}
$$

where $E_{\text {gvol }}$ it the actual current earnings growth volatility of firm $i$, measured as the standard deviation of the first difference in earnings, calculated between the end of year $t-3$ and $t$, and $E g v o l_{i, t-1}$ is the first non-overlapping lag of this variable. This specification allows us to focus on information available when investors form return expectations at the beginning of year $t$, and avoids overlapping observations 
of earnings growth volatility. We employ the predicted values from the autoregressive model as a measure of expected future earnings growth volatility used to form expectations about stock returns. For robustness, we re-estimate the autoregressive model using a number of different lag structures (3 and 5 years).

We view total future earnings growth volatility as the sum of systematic and idiosyncratic factors, that may arise from macroeconomic or firm-specific sources of earnings growth risk. We aim to empirically separate the effects of these two distinct sources of earnings growth risk. To do so, we employ a set of firm-by-firm projections of total future earnings growth volatility on measures of macroeconomic and firm-specific earnings growth volatility. First, we project each firm's time series of total future earnings growth volatility on a commonly employed measure of macroeconomic volatility, the volatility of industrial production growth (Bansal, Kiku, Shaliastovich, and Yaron, 2012), as follows:

$$
\text { Egvol }_{i t}=\alpha_{i}+\beta_{1} \text { MacroVol }_{t}+\epsilon_{i t}
$$

where Egvol $_{i t}$ is the actual current earnings growth volatility of firm $i$, measured as the standard deviation of the first difference in earnings, calculated between the end of year $t-3$ and $t$, and $M a c r o V o l$ is the the volatility of industrial production growth, measured as the standard deviation of the growth in industrial production, calculated between the end of year $t-3$ and $t$. Here, for practical purposes, we assume the availability of suitable macroeconomic forecasts. Then, we employ the predicted values from these projections as our measure of systematic future earnings growth volatility, that is induced by volatility in the macroeconomy. To obtain a measure of idiosyncratic earnings growth volatility, we collect the residuals from these projections.

Alternatively, we employ the dispersion of analyst forecasts of earnings one year ahead as a proxy of future idiosyncratic earnings growth volatility (Diether, Malloy, 
and Scherbina, 2002; Johnson, 2004). Here, we use earnings per share estimates, rather than the growth in these estimates, as subtracting all estimates from the current observation of realised earnings does not affect volatility (measured as the standard deviation). We calculate future idiosyncratic earnings growth volatility from annual forecast dispersion data measured as the standard deviation of monthly or quarterly, depending on availability, earnings forecasts and employ the mean estimate across analysts. This approach preserves the observations on firms with thin analyst coverage (one analyst).

\subsection{Empirical method}

We estimate the following pooled OLS regression of expected stock returns. Superscript $+/-$ denote the expected sign of the coefficient as per our hypotheses.

$$
\begin{aligned}
R_{i, t+1} & =\alpha_{i}+\beta_{1} \text { Lev }_{i t}+\beta_{2} E P_{i t}+\overbrace{\beta_{3} L e v 25_{i t}}^{\mathrm{H} 1:+}+\beta_{4} E_{g v o l}+\overbrace{\beta_{5} E g v o l 25_{i t}}^{\mathrm{H} 2:-} \\
& +\beta_{6} A B E T A_{i t}+\beta_{7} B M_{i t}+\beta_{8} \operatorname{Cap}_{i t}+\beta_{9} N O A_{i t}+\beta_{10} A c c_{i t}+\beta_{11} I s s_{i t} \\
& +\beta_{12} A G_{i t}+\beta_{13} L A G_{i t}+\beta_{14} M V_{i t}+\beta_{15} B H 6_{i t}+\beta_{16} B H 36_{i t}+\epsilon_{i t}
\end{aligned}
$$

where $R_{i t}$ is the annual return on firm $i$ measured from July $t$ to June $t+1$. We lag all independent variables by one year in order to reflect only information that is available when investors form expectations about stock returns for year $t$. Standard errors are clustered by firm (Petersen, 2009; Thompson, 2011).

Prior literature suggests a positive sign on $\beta_{1}$ measuring the impact of leverage Lev $_{i t}$ (Bhandari, 1988), defined as market leverage as in Titman, Wei, and Xie (2004). The variable $E P_{i t}$ is the earnings-to-price ratio (Basu, 1983; Fama and French, 1992), which we employ as a measure of expected future earnings growth, anticipating a positive sign on $\beta_{2}$. Coefficient $\beta_{3}$ measures the influence of an interaction term between leverage and a dummy variable for firms with low expected future earnings growth, Lev2 $5_{i t}$. These firms are defined as having earnings-to-price 
ratios in the top $25 \%$ in their respective 2-digit SIC group in year $t$. Hypothesis 1 suggests a positive sign on this coefficient, reflecting the increased sensitivity to leverage of low-growth firms relative to high-growth firms. Coefficient $\beta_{4}$ captures the impact of future earnings growth volatility $E_{g v o l}$. Consistent with the contingent claims framework, we anticipate a negative sign on $\beta_{4}$, reflecting the positive effect of volatility on the price of equity, which reduces expected stock returns. Hypothesis 2 suggests that the coefficient $\beta_{5}$ on the interaction between Egvol and the low-growth firm dummy, Egvol $25_{i t}$, should be significant and carry a negative sign, reflecting the increased sensitivity to future earnings growth volatility of low-growth firms relative to high-growth firms.

We control for a set of potentially value-relevant firm characteristics, largely following Cooper, Gulen, and Schill (2008): ABET $A_{i t}$ is the firm's asset beta (delevered equity beta), where the equity beta is estimated by regressing each individual firm's monthly excess returns on the monthly risk premium of the market over five years prior to the observation year. $B M_{i t}$ is the book-to-market ratio (Rosenberg, Reid, and Lanstein, 1985; Stattman, 1980). Capit is capital expenditure and investment (Titman, Wei, and Xie, 2004). NOA $A_{i t}$ is the ratio of net operating assets to total assets (Hirshleifer, Hou, Teoh, and Zhang, 2004). Further, Accit is accruals (Sloan, 1996). Iss $s_{i t}$ is issuance (Pontiff and Woodgate, 2008). $A G_{i t}$ and $L A G_{i t}$ are the (lagged) values of asset growth (Cooper, Gulen, and Schill, 2008). $M V_{i t}$ is firm size (Banz, 1981; Keim, 1983). $B H 6_{i t}$ and $B H 36_{i t}$ are the 6 - and 36 -month buy and hold returns (DeBondt and Thaler, 1985; Jegadeesh and Titman, 1993).

\subsection{Descriptive statistics}

Table 1 reports the sample firm characteristics over the study period 1962 to 2013. Over this period, the average annual total return on the stocks in the sample was $6 \%$. Mean leverage has a mean $21 \%$, consistent with the industrial capital structure literature (20\% to $28 \%$ market leverage on average). The mean earnings 
to price ratio is $2 \%$, while the median is $6 \%$, reflecting the influence of sample years with significantly negative earnings. The book-to-market ratio is 1.23 on average. Earnings growth volatility averaged $111 \%$ over the sample period, with a wide dispersion around this mean, suggesting significant variation in earnings risk across the sample firms over the study period. The asset beta (de-levered equity beta) of the sample firms averaged 0.93 over the study period, suggesting an almost directly proportional relationship with the wider stock market.

[Insert Table 1 about here.]

Table 2 reports the sample firm characteristics over the study period 1962 to 2013 sorted into earnings-to-price ratio deciles. The table suggests that firms with a high earnings-to-price ratio also tend to have high book-to-market ratios. This observations suggests that these two measures reflect complementary aspects of growth expectations. The book-to-market ratio focuses on the growth potential in the value of assets. Conversely, the earnings-to-price ratio focuses on the income growth potential implied the firm's growth opportunities. Further, the table suggests that low-growth firms have significantly lower future earnings growth volatility. This observation suggests that low-growth firms are significantly more stabilised than firms with larger growth potential. The table also suggests that there is no significant difference in the levels of leverage in low- and high-growth firms. We argue that the price of equity of low-growth firms is more sensitive to the distributional effects of leverage, theoretically suggesting that low-growth firms should carry lower leverage. However, Jung, Kim, and Stulz (1996) argue that leverage has a positive impact on firm value in low-growth firms because it disciplines managers to refrain from dispensing cash flow into wasteful investment projects, theoretically suggesting that low-growth firms should carry higher leverage. On balance, these two factors may cancel out in the data. The combined influence of these two factors may thus explain the lack of significance of the leverage spread across low-and high-growth firms. 
[Insert Table 2 about here.]

Table 3 reports the pairwise Pearson correlation coefficients between the predictors. The table shows a numerically small level of correlation between the bookto-market ratio and the earnings-to-price ratio. However, there are a number of large values for the book-to-market ratio even after winsorising at 1st and 99th percentiles. When we restrict to book-to-market ratio to less than 2 , then the correlation between book-to-market ratio and earnings-to-price ratio increases to 15\% (significant at the $10 \%$ level), suggesting that both statistics measure aspects of growth opportunities for the firm. More generally, the table shows low levels of correlation among the predictors, reducing concerns about multicollinearity.

[Insert Table 3 about here.]

\section{Results}

\subsection{Total future earnings growth volatility and expected stock returns}

Table 4 presents the main regression results. Our empirical findings are consistent with prior theoretical and empirical work on the positive relationships between leverage and expected stock returns, as well as the earnings-to-price ratio and expected stock returns, respectively (Basu, 1983; Bhandari, 1988). In addition however, consistent with Hypothesis 1, we find that leverage and expected future earnings growth significantly interact to increase expected stock returns.

[Insert Table 4 about here.]

Our finding has three main implications. First, prior research on the impact of leverage and the earnings-to-price ratio on stock returns generally considers the effects of these firm characteristics in isolation from each other. However, we find that, in addition to their individual marginal effects, these characteristics reinforce each 
other in determining expected stock returns. Higher leverage implies that a larger share of a given level of accumulated earnings is distributed to debt holders, rather than to equity holders as residual claimants. A higher earnings-to-price ratio suggests lower expected future earnings growth. Our finding suggests that the positive impact of leverage on stock returns is significantly larger for low-growth firms than for high-growth firms. Our finding is consistent with the rationale that equity holders of low-growth firms require compensation for the increased exposure of their equity claim to the distributional effects of leverage. For a given level of leverage, higher expected future earnings growth produces earnings that primarily accrue to equity holders as residual claimants. Firms with high expected future earnings growth are thus less sensitive to the effect of leverage on the price of the residual equity claim.

Second, prior research on the effect of leverage on stock returns as a function of growth opportunities often focuses on the asset value component of these growth opportunities, measured as the book-to-market ratio (Jung, Kim, and Stulz, 1996; McConnell and Servaes, 1995; Stulz, 1990). We find that the effect of leverage on stock returns is a function of the earnings component of growth opportunities, measured as the earnings-to-price ratio. Further, prior research finds that leverage increases firm value for firms with low growth opportunities as it disciplines managers, but decreases firm value for firms with high growth opportunities as it inhibits the pursuit of positive NPV projects. Our result suggests that the differential impact of leverage on low- versus high-growth firms is driven by the distributional effects of leverage, which are mitigated by higher future earnings growth.

Third, the book-to-market ratio remains significant in our regression including the earnings-to-price ratio and the interaction between leverage and the earnings growth indicator. This finding is consistent with our argument that the earnings-toprice ratio and the book-to-market ratio capture two complementary components of a firm's growth opportunities, income and asset growth. As a result, our find- 
ing allows us to propose a rational explanation for a positive return premium on value firms (low-growth firms with a high earnings-to-price ratio) relative to growth firms (high-growth firms with a low earnings-to-price ratio). Specifically, our finding suggests that this return premium reflects the marginal compensation required by equity holders of low-growth firms for the increased exposure of their residual equity claim to the distributional effects of leverage, as debt and equity holders share the benefits of a given amount of accumulated earnings, with a larger share of these earnings accruing to debt holders as leverage increases. Higher future earnings growth attenuates the distributional effects of leverage, reducing expected returns on high-growth firms relative to low-growth firms.

Many researchers have suggested explanations for the return premium commonly delivered by value firms over growth firms. Vassalou (2003) and Aretz, Bartram, and Pope (2010) relate this premium to a set of macroeconomic variables that proxy for shifts in the investment opportunity set. ${ }^{7}$ Fama and French (1996) and Garcia-Feijoo and Jorgensen (2010) suggest that this return premium reflects compensation for systematic risks beyond the market factor, such as default risk or operating leverage. Penman and Reggiani (2011) and Penman, Reggiani, Richardson, and Tuna (2011) argue that the return premium on value firms results from current accounting practice for accommodating earnings risk. In contrast, Lakonishok, Shleifer, and Vishny (1994) and Daniel and Titman (1997) suggest behavioural explanations, arguing that this return premium reflects mispricing based on cognitive biases among investors. ${ }^{8}$ Our findings suggest an alternative rational explanation for the return premium on low-growth (value) firms. Our explanation is ultimately driven by the difficulty to fully hedge earnings risk. Expected future earnings growth, which we employ to distinguish value firms from growth firms according to the in-

\footnotetext{
7 Other studies in this macroeconomic context include Ghargori, Chan, and Faff (2007); Hahn and Lee (2006); Kelly (2004); Liew and Vassalou (2000); Petkova (2006).

8 Studies in a similar vein also include Hall and Tochterman (2008); Kothari, Shanken, and Sloan (1995); Lo and MacKinlay (1990); Shumway and Warther (1999).
} 
come component of growth opportunities, is a significant determinant of the price of equity because there is an incomplete market for earnings. The difficulty to construct a replicating portfolio for earnings then also drives the significance of the interaction between the earnings growth indicator and leverage, generating the positive return differential between low- and high-growth firms.

The relative difference in the impact of leverage on the expected stock returns from low- and high-growth firms is also economically significant. A one standard deviation increase in leverage $(0.22)$ results in a $2.73 \%$ increase in expected annual returns for high-growth firms and a significantly higher $4.15 \%$ increase for low-growth firms.

Consistent with the contingent claims framework, we find that future earnings growth volatility is inversely related to expected stock returns. Our finding suggests that total future earnings growth volatility, rather than its systematic component only, has a significant impact on expected stock returns. Our finding supports the argument proposed in Goyal and Santa-Clara (2003) that total risk matters to investors. Further, our finding suggests that total risk surrounding expected future earnings growth reduces expected stock returns. Our finding resonates the argument presented in Johnson (2004) that volatility makes a positive contribution to the value of equity in a contingent claims framework. However, Johnson (2004) finds that it is idiosyncratic volatility that makes this positive contribution. We explore the relative impact of systematic versus idiosyncratic future earnings growth volatility in Section 4.2. Our finding here is consistent with our argument that total earnings growth volatility generates the potential of positive future earnings growth, even when expected future growth is low. For a given level of leverage, this growth potential primarily benefits equity holders as residual claimants. For equity holders, this potential is upside-only, as the pay-off from the equity claim as a call on earnings is bounded from below, generating the positive contribution of total volatility to the 
price of equity.

In line with Hypothesis 2, we find that the interaction between future earnings growth volatility and the indicator for low-growth firms is inversely related to expected stock returns. Our finding suggests that the upside-only potential of future earnings growth implied in a volatile earnings growth process is more valuable in a firm low expected future earnings growth. Goyal and Santa-Clara (2003) argue that total risk matters in the case of limited diversification induced by market frictions or the impact of private information or habit on investment choices. Our result suggests that total risk surrounding future earnings growth matters, and especially that it affects low- and high-growth firms differently, not due to frictions or investor biases, but because there is an incomplete market for earnings. Analogous to the interaction of expected future earnings growth and leverage, the difficulty to replicate earnings drives the significance of the interaction between expected future earnings growth and future earnings growth volatility in determining the price of equity.

Again, the relative difference in the impact of future earnings growth volatility on the expected stock returns from low- and high-growth firms is economically significant. A one standard deviation increase in total earnings growth volatility (2.74) results in a $2.90 \%$ reduction in expected annual returns for high-growth firms. For low-growth firms, the negative effect is significantly stronger with a reduction of $4.90 \%$. On balance however, the increased sensitivity of low-growth firms to the impact of leverage (positive impact on expected stock returns) outweighs the increased sensitivity of low-growth firms to the impact of future earnings growth volatility as a higher-order term in the value-generating process (negative impact on expected stock returns). As a result, even in the presence of future earnings growth volatility, our findings suggest a net positive return premium on firms with low expected future earnings growth (value firms). 
Our findings on the link between total future earnings growth volatility and stock returns only have practical relevance for investors if firms with high and low earnings growth volatility can be identified ex ante. The earnings-to-price ratio already reflects investor expectations of future growth. In order to capture expectations of future earnings growth volatility, we employ the conditional expectation of total future earnings growth volatility from an autoregressive model as a proxy in our regression. The construction of this proxy only requires information available to investors when they form expectations about stock returns.

Columns 2 to 4 of Table 4 show that the evidence for the link between total future earnings growth volatility and stock returns is robust to using this proxy, across a range of alternative lag structures. Our finding implies a significant degree of persistence in earnings growth volatility. The observation of persistence in earnings and the significant information content of past earnings volatility is consistent with Frankel and Litov (2009) and Dichev and Tang (2009, 2008). Our findings suggest that information about past earnings growth volatility may be useful for guiding future capital allocation and investment decisions.

In these regressions, the coefficient on the book-to-market ratio, as the traditional measure of the asset value component of growth opportunities, is significant again. Our finding suggests that the autoregressive model generating the conditional expectation of future earnings growth volatility, which acts as a proxy for the uncertainty surrounding the income component of growth opportunities, contains an estimation error. Our finding thus implicitly suggests that the book-to-market ratio captures not only expectations about future growth opportunities as they relate to anticipated growth in the value of assets, but also indirectly reflects some of the uncertainty surrounding these growth opportunities. 


\subsection{Decomposing future earnings growth volatility}

The total volatility of a firm's earnings growth process arguably comprises elements of macroeconomic (systematic) and firm-specific (idiosyncratic) risks. These elements may reflect the effects of factors such as fluctuations in the business cycle or the uncertainty surrounding the outcomes of managerial decisions. Next, we explore the canonical influence of the systematic and idiosyncratic components of future earnings growth volatility and examine how these distinct sources of future earnings growth risk influence the expected stock returns of low- and high-growth firms, as per Hypotheses 2 and 3. Table 5 presents the results.

[Insert Table 5 about here.]

Column 1 of Table 5 considers systematic earnings growth volatility as induced by macroeconomic volatility, and idiosyncratic earnings growth volatility as the residual element of total earnings growth volatility that is unexplained by macroeconomic volatility. We find that systematic earnings growth volatility reduces expected stock returns, reflecting the upside-only potential of earnings growth implied in a volatile earnings process. However, we find that after controlling for systematic earnings growth volatility, the main effect of the residual idiosyncratic component of earnings growth volatility is insignificant.

Our findings have several implications. First, prior research on the relationship between volatility and stock returns often implicitly assumes aggregate volatility to be constant (Campbell, 1996). However, our results suggest that variation in the macroeconomic component of future earnings growth volatility has a significant impact on expected stock returns. Second, some studies that explore the impact of variation in macroeconomic volatility on stock returns adopt an approach of directly relating a measure of macroeconomic volatility to stock returns (Bansal, Kiku, Shaliastovich, and Yaron, 2012; Bansal, Kiku, and Yaron, 2007; Bansal and Yaron, 
2004; Drechsler and Yaron, 2011). This approach makes it difficult to identify the channels through which macroeconomic volatility is transmitted to stock returns. Our approach allows us to trace the impact of macroeconomic volatility on expected stock returns through its influence on the volatility of the firm's earnings growth process, which is a fundamental driver of the price of equity in our modelling framework. At the same time, our findings suggest that the impact of macroeconomic volatility on the firm's earnings growth process dominates the influence of the residual idiosyncratic components of earnings growth volatility in the determination of expected stock returns. Third, the aforementioned studies generally find a positive relationship between macroeconomic volatility risks and stock returns. Our results suggest that macroeconomic volatility, to the extent it is reflected in the volatility of the firm's earnings growth process, reduces expected stock returns. However, our finding does not directly contradict prior evidence because we do not rule out that the effects of macroeconomic volatility on other components of the firm's underlying value-generating processes may increase expected stock returns.

Consistent with the basic premise of Hypothesis 2, we find that low-growth firms are more sensitive to both types of future earnings growth volatility. More specifically however, we find that the increased exposure of low-growth firms to macroeconomic volatility increases expected stock returns relative to high-growth firms. Our finding is consistent with studies suggesting that low-growth (value) firms command a return premium relative to high-growth (growth) firms because these stocks are more sensitive to macroeconomic volatility risks (Ai and Kiku, 2013; Bansal, Dittmar, and Kiku, 2009; Bansal, Dittmar, and Lundblad, 2005; Barinov, 2013; Hansen, Heaton, and Li, 2008; Lettau and Wachter, 2007). This return premium is commonly attributed to the variation in cash flow sensitivity to macroeconomic risks along the expected growth dimension. Our results suggest that the reason why the sensitivity of firm cash flows to macroeconomic risks decreases in expected growth is the increased sensitivity of low- and high-growth firms to the distributional effects of 
leverage. This increased sensitivity is a significant characteristic of low-growth firms, which we identify using the earnings-to-price ratio indicator. The positive sign of the coefficient on the interaction between systematic future earnings growth volatility and the low-growth firm indicator suggests that the increased sensitivity of lowgrowth firms to the distributional effects of leverage (positive impact on expected stock returns) economically outweighs the increased sensitivity of these firms to the influence of future earnings growth volatility (negative impact on expected stock returns) as a higher-order term in the firm's value-generating process.

Further, consistent with Hypothesis 2, we find that the increased exposure of low-growth firms to the residual idiosyncratic component of future earnings growth volatility reduces expected stock returns. Our finding resonates the argument proposed in Avramov, Cederburg, and Hore (2012) that low relative share firms, which display low cash flow duration (low-growth firms), are more susceptible to firmspecific dividend shocks. ${ }^{9}$ However, our result implicitly suggests that the increased sensitivity to dividend shocks may partly be related to increased sensitivity to idiosyncratic risks in the firm's earnings growth process, which determines the cash flow available for distribution to shareholders as dividends.

Column 2 of Table 5 also considers systematic earnings growth volatility as induced by macroeconomic volatility, but idiosyncratic earnings growth volatility is proxied by the dispersion of analyst forecasts of future earnings. The empirical evidence continues to support our earlier finding for this alternative measure of idiosyncratic future earnings growth volatility. Our finding concurs with the inverse relationship between stock returns and analyst forecast dispersion reported in a number of recent studies (Ang, Hodrick, Xing, and Zhang, 2006, 2009; Diether, Malloy, and Scherbina, 2002; Lehmann, 1990; Malkiel and Xu, 1997, 2002). Our

$\overline{9}$ The cash flow duration of a firm is positively related to its expected dividend growth, summarised by the relative share measure, defined as the long-run expected dividend share of a firm as a proportion of its current dividend share, with dividend share being the fraction of the dividend paid by the firm relative to the aggregate dividend (Menzly, Santos, and Veronesi, 2004). Similar duration-based studies include for instance Bansal, Dittmar, and Lundblad (2005); Hansen, Heaton, and Li (2008); Lettau and Wachter (2007). 
results also concur with the options-based explanation for this empirical observation suggested in Johnson (2004). However, we find that analyst forecast dispersion as an alternative measure subsumes the previously significant influence of systematic volatility and the interaction between the expected future earnings growth indicator and the volatility measures. Our result suggests that earnings forecast dispersion is a strong catch-all variable that jointly reflects a variety of risk factors influencing the firm's future earnings growth. While this characteristic renders forecast dispersion a statistically powerful measure, our results suggest that the breadth of risk factors captured by this measure may conceal some of the more subtle interactions between different sources of risk impacting upon the firm's earnings growth process, the firm's expected future earnings growth and its expected stock returns.

In all of our regressions, we account for a broad set of control variables that have been found to be significantly related to stock returns. These variables include the firm's asset beta (de-levered equity beta), its market value, lagged buy-and-hold returns (over 6 and 36 months) and additional determinants that may be related to growth rates, such as accruals and capital investment. Our main variables of interest are not subsumed by the other determinants of stock returns, in fact our variables of interest are among the most highly significant predictors.

\section{Robustness tests}

We have carried out a number of additional tests in order to examine the robustness of our results. We present and discuss the main findings below.

In our main analysis, we define firms with low expected future earnings growth as those with earnings-to-price ratios in the top $25 \%$ in their respective 2-digit SIC group in a given year. However, while intuitively appealing, we have no stringent rationale for favouring this particular cut-off. For robustness, we replace this cutoff point with a range of alternatives, and replicate our analysis with low-growth 
firms defined as those in the top $33 \%$ and $50 \%$. Table 6 presents the results. Our conclusions are robust to these alternative definitions of low-growth firms.

[Insert Table 6 about here.]

We also incorporate a number of additional control variables into our empirical analysis to further stress-test our findings. Table 7 presents the results. In our main analysis, we focus on the earnings-to-price ratio of the firm as a measure of expected future earnings growth. Some studies argue in favour of the use of cash dividend data as a proxy of the value-relevant income that investors focus on. However, several authors argue that dividends may not be a reliable measure of value-relevant income, and thus distort empirical inference (Ang and Bekaert, 2007; Bansal, Khatchatrian, and Yaron, 2005; Bansal and Yaron, 2004). Our model relies on earnings as the central driver of the price of equity, an easily observable and reliably measurable accounting quantity (Alcock, Mollee, and Wood, 2011; Apabhai, Georgikopoulos, Hasnip, Jamie, and Kim, 1999; Epstein, Mayor, Schönbucher, Whalley, and Wilmott, 1998; Li, 2003). We do not attempt to model the dividend pay-out decision. Nevertheless, for robustness, we also include the dividend yield in an alternative estimation. Our results are robust to this additional control variable (Column 1 in Table Table 7).

The literature suggests a positive sign on on the regression coefficient measuring the impact of leverage (Bhandari, 1988), defined as market leverage as in Titman, Wei, and Xie (2004). Leverage captures aspects of default risk. For robustness, we also actively control for the default risk (using Altman's z-score) that may be associated with higher firm leverage. Our findings are robust to including this additional control (Column 2 in Table 7). Our results regarding the impact of future earnings growth volatility on the expected stock returns of low-and high expected future earnings growth firms are qualitatively similar when controlling for non-linearities in the relationships between leverage and expected stock returns (Column 3 in Table 
7). In addition, our results are also robust to controlling for industry and year fixed effects (Columns 4 and 5 in Table 7).

Further, we have carried out a number of robustness checks on our measures of systematic and idiosyncratic volatility employed in the findings presented in Table 5. Table 8 presents the results of these robustness checks. In our main analysis, we have projected firm-level total future earnings growth volatility on the volatility of industrial production growth (Bansal, Kiku, Shaliastovich, and Yaron, 2012). For robustness, we employ the VIO version of the VIX, available from 1986 onwards, as a proxy for macroeconomic volatility (Ang, Hodrick, Xing, and Zhang, 2006). Our results are robust to using this measure (Column 1 in Table 8).

In our main analysis, we calculate future idiosyncratic earnings growth volatility from annual forecast dispersion data measured as the standard deviation of monthly or quarterly, depending on availability, earnings forecasts and employ the mean estimate across analysts. For robustness, we also employ the median estimate across analysts. Our results are robust to this alternative measure (Column 2 in Table 8).

Furthermore, our main findings suggest that a higher earnings-to-price ratio is associated lower expected future earnings growth. Conversely, a low earningsto-price ratio does not necessarily always indicate strong expected future earnings growth. For instance, negative earnings-to-price ratios, driven by negative earnings, primarily suggest low profitability. For robustness, we exclude observations where the earnings-to-price ratio is negative. Lastly, for completeness, we also add an indicator variable for low growth firms with an earnings-to-price ratio in the top $25 \%$ in their respective 2-digit SIC group in year $t$, in order to better isolate the main effect of this group from the interactions with leverage and future earnings growth volatility. Our conclusions regarding the inverse relationship between future earnings growth volatility and expected stock returns, as well as the increased sensitivity of lowgrowth firms to the effects of future earnings growth volatility, remain unchanged. 
The results of these additional robustness checks can be made available upon request.

\section{Conclusion}

We employ a stochastic earnings valuation model to examine the interrelationships between leverage, expected future earnings growth, future earnings growth volatility and the price of equity. Our approach enables us to propose a rational explanation for an expected return premium on low-growth (value) firms relative to high-growth (growth) firms. Furthermore, we contribute to the question how systematic and idiosyncratic components of volatility risks impact upon expected stock returns.

We derive three main implications from our model, for which we find statistically and economically significant empirical evidence. First, the price of equity for firms with low expected future earnings growth is more sensitive to leverage than that of firms with high expected future earnings growth. This increased sensitivity requires compensation in the form of higher expected returns on firms with low expected future earnings growth. Second, the upside-only potential of positive future earnings growth implied in a volatile earnings growth process increases the price of equity, giving rise to an inverse relationship between future earnings growth volatility and expected stock returns. Our finding in relation to the impact of future earnings growth volatility on stock returns is robust to employing a proxy for this volatility that utilises only information available to investors at the time of forming expectations about stock returns. Third, firms with low expected future earnings growth are more sensitive to future earnings growth volatility, as the upside potential of positive growth implied in a volatile earnings growth process is more valuable when expected growth is low, reducing expected returns on low-growth firms relative to high-growth firms. Economically however, the effect of the increased exposure of low-growth firms to the effects of leverage dominates their increased exposure to the 
effects of future earnings growth volatility, on balance again producing a positive return premium for low-growth (value) firms.

Further, our approach enables us to present evidence how systematic and idiosyncratic components of future earnings growth volatility are transmitted to expected stock returns, and to differentiate their influence across low- and high-growth firms. We find that systematic and idiosyncratic volatility in future earnings growth increase the price of equity for a levered firm. In addition, we find that low-growth firms are significantly more sensitive to both types of volatility than high-growth firms. However, our evidence also suggests that the positive marginal contribution of volatility to the price of equity for low-growth firms is primarily driven by idiosyncratic volatility, while the higher sensitivity of value firms to systematic volatility increases expected returns on low-growth firms relative to high-growth firms. 


\section{References}

AI, H., AND D. KIKU (2013): "Growth to value: Option exercise and the cross section of equity returns," Journal of Financial Economics, 107(2), 325-349.

Alcock, J., T. Mollee, And J. Wood (2011): "Volatile earnings growth, the price of earnings and the value premium," Quantitative Finance, 11(6), 805-815.

Ang, A., And G. Bekaert (2007): "Stock Return Predictability: Is it There?" Review of Financial Studies, 20(3), 651-707.

Ang, A., R. J. Hodrick, Y. Xing, And X. Zhang (2006): "The Cross-Section of Volatility and Expected Returns," Journal of Finance, 61(1), 259-299.

(2009): "High idiosyncratic volatility and low returns: International and further US evidence," Journal of Financial Economics, 91(1), 1-23.

Apabhai, M., N. Georgikopoulos, D. Hasnip, R. Jamie, and M. Kim (1999): "Model for the Value of a Business, Some Optimisation Problems in its Operating Procedures and the Valuation of its Debt," Working paper, Oxford Financial Research Centre.

Aretz, K., S. M. Bartram, and P. F. Pope (2010): "Macroeconomic risks and characteristic-based factor models," Journal of Banking and Finance, 34(6), $1383-1399$.

Avramov, D., S. Cederburg, And S. Hore (2012): "Cross-Sectional Asset Pricing Puzzles: A Long-Run Perspective," Working Paper.

Bali, T., N. Cakici, X. S.Yan And Z. Zhang (2005): "Does idiosyncratic risk really matter?," Journal of Finance, 60(2), 905-929.

Bansal, R., R. Dittmar, And D. Kiku (2009): "Cointegration and Consumption Risks in Asset Returns," Review of Financial Studies, 22(3), 1343-1375.

Bansal, R., R. F. Dittmar, and C. T. Lundblad (2005): "Consumption, Dividends, and the Cross Section of Equity Returns," Journal of Finance, 60(4), 1639-1672.

Bansal, R., V. Khatchatrian, and A. Yaron (2005): "Interpretable asset markets?," European Economic Review, 49(3), 531-560.

Bansal, R., D. Kiku, I. Shaliastovich, and A. Yaron (2012): "Volatility, the Macroeconomy and Asset Prices," Working Paper 18104, National Bureau of Economic Research.

Bansal, R., D. Kiku, And A. Yaron (2007): "Risks For the Long Run: Estimation and Inference," Working Paper.

Bansal, R., And A. Yaron (2004): "Risks for the Long Run: A Potential Resolution of Asset Pricing Puzzles," Journal of Finance, 59(4), 1481-1509.

BANZ, R. W. (1981): "The relationship between return and market value of common stocks," Journal of Financial Economics, 9(1), 3-18.

BARINov, A. (2013): "Analyst Disagreement and Aggregate Volatility Risk," Journal of Financial and Quantitative Analysis, Forthcoming.

Barron, O. E., M. H. Stanford, and Y. Yu (2009): "Further evidence on the relation between analysts' forecast dispersion and stock returns," Contemporary Accounting Research, 26(2), 329-357.

BASU, S. (1983): "The relationship between earnings' yield, market value and return for NYSE common stocks: Further evidence," Journal of Financial Economics, 12(1), 129-156.

BHANDARI, L. C. (1988): "Debt/equity ratio and expected common stock returns: empirical evidence," Journal of Finance, 43(2), 507-528.

Black, F., AND M. Scholes (1972): "The valuation of option contracts and a test 
of market efficiency," Journal of Finance, 27(2), 399-418.

Campbell, J. (1996): "Understanding Risk and Return," Journal of Political Economy, 104(2), 298-345.

Chor, J. Y. (2013): "What drives the value premium?: the role of asset risk and leverage," Review of Financial Studies, 26(11), 2845-2875.

Ciftci, M. And W. CREady (2011): "Scale effects of R\&D as reflected in earnings and returns," Journal of Accounting and Economics, 52(1), 62-80.

Cooper, M. J., H. Gulen, And M. J. Schill (2008): "Asset growth and the cross-section of stock returns," Journal of Finance, 63(4), 1609-1651.

Daniel, K., And S. Titman (1997): "Evidence on the characteristics of cross sectional variation in stock returns," Journal of Finance, 52(1), 1-33.

- (2006): "Market Reactions to Tangible and Intangible Information," Journal of Finance, 61(4), 1605-1643.

Davis, J. L., E. F. Fama, And K. R. French (2000): "Characteristics, Covariances, and Average Returns: 1929 to 1997," Journal of Finance, 55(1), 389-406.

DeBondt, W. F. M., and R. Thaler (1985): "Does the Stock Market Overreact?," Journal of Finance, 40(3), 793-805.

DicheV, I., AND V. TANG (2009): "Earnings volatility and earnings predictability," Journal of Accounting and Economics, 47(1-2), 160-181.

Dichev, I. D., And V. W. TANG (2008): "Matching and the changing properties of accounting earnings over the last 40 years," Accounting Review, 86(6), 945-974.

Diether, K. B., C. J. Malloy, And A. Scherbina (2002): "Differences of Opinion and the Cross Section of Stock Returns," Journal of Finance, 57(5), 21132141.

Drechsler, I., And A. Yaron (2011): "What's Vol Got to Do with It?," Review of Financial Studies, 24(1), 1-45.

Epstein, D., N. Mayor, P. Schönbucher, A. E. Whalley, and P. Wilmott (1998): "The valuation of a firm advertising optimally," Quarterly Review of Economics and Finance, 38(2), 149-166.

Fama, E. F., And K. R. French (1992): "The Cross-Section of Expected Stock Returns," Journal of Finance, 47(2), 427-465.

(1993): "Common risk factors in the returns on stocks and bonds," Journal of Financial Economics, 33(1), 3-56.

- (1996): "Multifactor explanations of asset pricing anomalies," Journal of Finance, 51(1), 55-84.

(2014): "A Five-Factor Asset Pricing Model," Working Paper.

Frankel, R., AND L. Litov (2009): "Earnings persistence," Journal of Accounting and Economics, 47(1-2), 182-190.

Garcia-Feijoo, L., And R. Jorgensen (2010): "Can operating leverage be the cause of the value premium?," Financial Management, 39(3), 1127-1154.

Garlappi, L., AND H. YAN (2010): "Financial Distress and the Cross-section of Equity Returns," Journal of Finance, 66(3), 789-822.

Ghargori, P., H. Chan, And R. FAfF (2007): "Are the Fama-French factors proxying default risk?," Australian Journal of Management, 32(2), 223-249.

Gomes, J., AND L. Schmid (2010): "Levered Returns," Journal of Finance, 65(2), 467-494.

Goyal, A., And P. Santa-Clara (2003): "Idiosyncratic Risk Matters!," Journal of Finance, 58(3), 975-1008.

Hahn, J., AND H. LeE (2006): "Yield Spreads as Alternative Risk Factors for Size and Book-to-Market," Journal of Financial and Quantitative Analysis, 41(2), 245- 
269.

Hall, J., And M. Tochterman (2008): "Persistence in growth versus market expectations," Australian Journal of Management, 33(1), 169-199.

Hansen, L. P., J. C. Heaton, and N. Li (2008): "Consumption Strikes Back? Measuring Long-Run Risk," Journal of Political Economy, 116(2), 260-302.

Henderson, V., AND R. Wojakowski (2002): "On the equivalence of floatingand fixed-strike asian options," Journal of Applied Probability, 39(2), 391-394.

Hirshleifer, D., K. Hou, S. H. TeOH, and Y. Zhang (2004): "Do investors overvalue firms with bloated balance sheets?, Journal of Accounting and Economics, 38(1), 297-331.

Jegadeesh, N., and S. Titman (1993): "Returns to Buying Winners and Selling Losers: Implications for Stock Market Efficiency," Journal of Finance, 48(1), 6591.

Johnson, T. C. (2004): "Forecast Dispersion and the Cross Section of Expected Returns," Journal of Finance, 59(5), 1957-1978.

JunG, K., Y.-C. Kim, AND R. Stulz (1996): "Timing, investment opportunities, managerial discretion, and the security issue decision," Journal of Financial Economics, 42(2), 159-186.

KeIm, D. B. (1983): "Size-related anomalies and stock return seasonality : Further empirical evidence," Journal of Financial Economics, 12(1), 13-32.

KeLly, P. J. (2004): "Real and inflationary macroeconomic risk in the Fama and French size and book-to-market portfolios," Working Paper.

Kothari, S. P., T. Laguerre, And A. Leone (2002): "Capitalization versus expensing: Evidence on the uncertainty of future earnings from capital expenditures versus R\&D outlays," Review of Accounting Studies, 7(4), 355-382.

Kothari, S. P., J. Shanken, And R. Sloan (1995): "Another look at the crosssection of exptected returns," Journal of Finance, 50(1), 185-224.

Lakonishok, J., A. Shleifer, and R. W. Vishny (1994): "Contrarian Investment, Extrapolation, and Risk," Journal of Finance, 49(5), 1541-1578.

Lehmann, B. N. (1990): "Residual risk revisited," Journal of Econometrics, 45(12), 71-97.

Lettau, M., And J. A. Wachter (2007): "Why Is Long-Horizon Equity Less Risky? A Duration-Based Explanation of the Value Premium," Journal of Finance, 62(1), 55-92.

LI, S. (2003): "A valuation model for firms with stochastic earnings," Applied Mathematical Finance, 10(3), 229-243.

Liew, J., AND M. VAssalou (2000): "Can book-to-market, size and momentum be risk factors that predict economic growth?," Journal of Financial Economics, $57(2), 221-245$.

Lo, A., And C. MacKinlay (1990): "Data-snooping biases in tests of financial asset pricing models," Review of Financial Studies, 3(3), 431-467.

Malkiel, B. G., AND Y. XU (1997): "Risk and Return Revisited," Journal of Portfolio Management, 23(3), 9-14.

- (2002): "Idiosyncratic risk and security returns," University of Texas at Dallas Working Paper.

McConnell, J. J., And H. Servaes (1995): "Equity ownership and the two faces of debt," Journal of Financial Economics, 39(1), 131-157.

Menzly, L., T. Santos, and P. Veronesi (2004): "Understanding Predictability," Journal of Political Economy, 112(1), 1-47.

Nielsen, J.A., And K. Sandmann (2003): "Pricing bounds on asian options," 
Journal of Financial and Quantitative Analysis, 38(2), 449-473.

ObrejA, I. (2013): "Book-to-Market Equity, Financial Leverage, and the CrossSection of Stock Returns," Review of Financial Studies, forthcoming.

Penman, S., And F. RegGiani (2011): "Returns to buying earnings and book value: Accounting for growth and risk," Review of Accounting Studies, Forthcoming.

Penman, S., F. Reggiani, S. A. Richardson, and I. Tuna (2011): "A characteristic model for asset pricing," Working Paper.

Petersen, M. (2009): "Estimating standard errors in finance panel data sets: comparing approaches," Review of Financial Studies, 22(1), 435-480.

Petkova, R. (2006): "Do the Fama-French Factors Proxy for Innovations in Predictive Variables?," Journal of Finance, 61(2), 581-612.

Pontiff, J., And A. Woodgate (2008): "Share Issuance and Cross-Sectional Returns," Journal of Finance, 63(2), 921-945.

Rogers, LCG., AND Z. SHi (1995): "The value of an Asian option," Journal of Applied Probability, 32(4), 1077-1088.

Rosenberg, B., K. Reid, And R. Lanstein (1985): "Persuasive evidence of market inefficiency," Journal of Portfolio Management, 11(3), 9-17.

Shumway, T., And V. A. Warther (1999): "The Delisting Bias in CRSP's Nasdaq Data and Its Implications for the Size Effect," Journal of Finance, 54(6), 23612379.

SlOAN, R. G. (1996): "Do Stock Prices Fully Reflect Information in Accruals and Cash Flows about Future Earnings?," Accounting Review, 71(3), 289-315.

Stattman, D. (1980): "Book values and stock returns," Chicago MBA: A Journal of Selected Papers, 4, 25-45.

Stulz, R. (1990): "Managerial discretion and optimal financing policies," Journal of Financial Economics, 26(1), 3-27.

Thompson, S. B. (2011): "Simple formulas for standard errors that cluster by both firm and time," Journal of Financial Economics, 99(1), 1-10.

Titman, S., K. C. J. Wei, And F. XIE (2004): "Capital Investments and Stock Returns," Journal of Financial and Quantitative Analysis, 39(4), 677-700.

Trigeorgis, L., AND N. Lambertides (2014): "The role of growth options in explaining stock returns," Journal of Financial and Quantitative Analysis, forthcoming.

VAssalou, M. (2003): "News related to future GDP growth as a risk factor in equity returns," Journal of Financial Economics, 68(1), 47-73. 


\section{A Returns on Small Firms}

Results for firm size (inversely related to EGVOL)

\begin{tabular}{|c|c|c|}
\hline & (1) & $(2)$ \\
\hline Dependent variable: Firm returns $t+1$ & Total EGV & Total EGV \\
\hline Cut-off ratios for Low Growth Dummy employed: & $33 \%$ & $50 \%$ \\
\hline Leverage x Low Growth Dummy (+) & $\begin{array}{l}0.0580^{* * * *} \\
(0.01)\end{array}$ & $\begin{array}{l}0.0735^{* * * *} \\
(0.01)\end{array}$ \\
\hline Market Value (\$Bils) & $\begin{array}{l}-0.0022^{* * *} \\
(0.01)\end{array}$ & $\begin{array}{l}-0.0034^{* * *} \\
(0.01)\end{array}$ \\
\hline Market Value (\$Bils) x Low Growth Dummy $(+)$ & $\begin{array}{c}0.0013^{*} \\
(0.00)\end{array}$ & $\begin{array}{l}0.0027^{* * * *} \\
(0.00)\end{array}$ \\
\hline Market Leverage & $\begin{array}{l}0.1301^{* * *} \\
(0.01)\end{array}$ & $\begin{array}{l}0.1171^{* * *} \\
\quad(0.01)\end{array}$ \\
\hline Earnings-to-price Ratio & $\begin{array}{l}0.0331^{* * * *} \\
(0.01)\end{array}$ & $\begin{array}{l}0.0256^{* *} \\
(0.01)\end{array}$ \\
\hline Book-to-market equity & $\begin{array}{l}0.0055^{* * *} \\
\quad(0.00)\end{array}$ & $\begin{array}{l}0.0055^{* * *} \\
\quad(0.00)\end{array}$ \\
\hline Asset Beta & $\begin{array}{l}0.0265^{* * *} \\
\quad(0.01)\end{array}$ & $\begin{array}{l}0.0267^{* * *} \\
\quad(0.01)\end{array}$ \\
\hline ACCRUALS & $\begin{array}{c}-0.0272 \\
(0.03)\end{array}$ & $\begin{array}{c}-0.0276 \\
(0.03)\end{array}$ \\
\hline Capital Expenditure & $\begin{array}{c}-0.0244 \\
(0.03)\end{array}$ & $\begin{array}{c}-0.0240 \\
(0.03)\end{array}$ \\
\hline Net Operating Assets & $\begin{array}{l}0.0236^{* *} \\
(0.01)\end{array}$ & $\begin{array}{l}0.0232^{* *} \\
(0.01)\end{array}$ \\
\hline Issuance & $\begin{array}{l}-0.1220^{* * *} \\
(0.01)\end{array}$ & $\begin{array}{l}-0.1217^{* * *} \\
(0.01)\end{array}$ \\
\hline Asset Growth & $\begin{array}{l}-0.0948^{* * *} \\
(0.01)\end{array}$ & $\begin{array}{c}-0.0944^{* * *} \\
(0.01)\end{array}$ \\
\hline Lag of Asset Growth & $\begin{array}{c}-0.0259 * * * \\
(0.00)\end{array}$ & $\begin{array}{c}-0.0256^{* * *} \\
(0.00)\end{array}$ \\
\hline 6-month BHRET & $\begin{array}{c}-0.0005 \\
(0.01)\end{array}$ & $\begin{array}{c}-0.0005 \\
(0.01)\end{array}$ \\
\hline 36-month BHRET & $\begin{array}{c}-0.0154^{* * * *} \\
(0.00)\end{array}$ & $\begin{array}{c}-0.0153^{* * *} \\
(0.00)\end{array}$ \\
\hline Constant & $\begin{array}{c}0.0158^{*} \\
(0.01)\end{array}$ & $\begin{array}{c}0.0152^{*} \\
(0.01)\end{array}$ \\
\hline Observations & 63,959 & 63,959 \\
\hline
\end{tabular}

Table A.1

The table presents the main regression results for the sample firms estimated as a pooled OLS regression over the period 1962-2013. All variables are defined as in Table 1. Independent variables are lagged by one year in order to employ only information that is available when investors form expectations about returns in year $t+1$. The regressions employ actual future earnings growth volatility, defined as the standard deviation of the first difference in actual earnings that are measured between the end of year $t$ and $t+3$. Robust standard errors, clustered by firm, are shown in parentheses. Predicted signs for the main variables of interest are also shown in parentheses. Significance is indicated as follows: ${ }^{* * *} \mathrm{p}<0.01,{ }^{* *} \mathrm{p}<0.05,{ }^{*} \mathrm{p}<0.10$. 


\section{Figures and Tables}

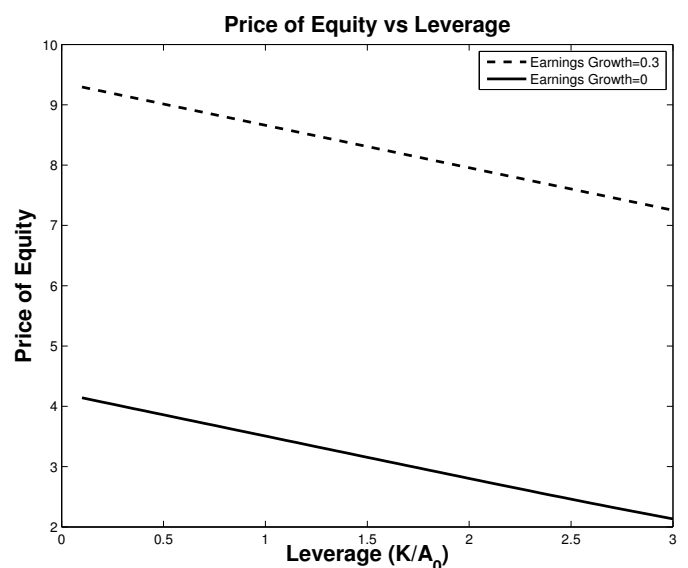

(a) The price of equity and leverage

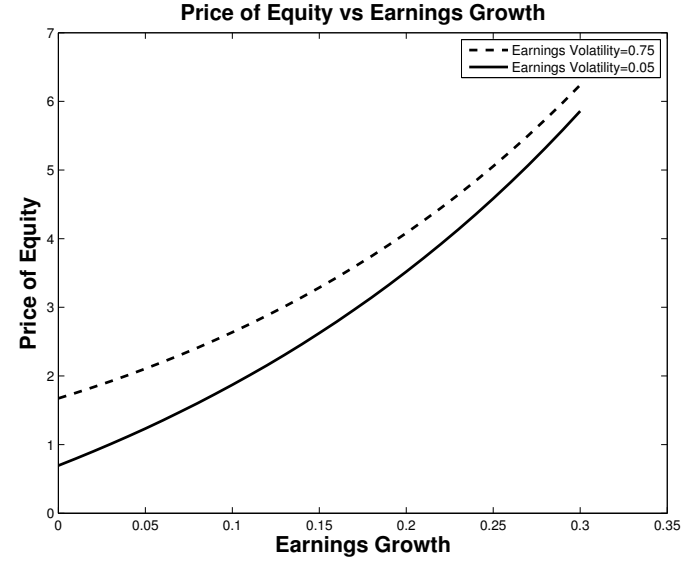

(b) The price of equity and earnings growth volatility

Fig. 1. The figure illustrates the relationships between the price of equity, leverage, expected earnings growth and earnings growth volatility. Leverage is measured as the face value of debt $(K)$ relative to initial assets $\left(A_{0}\right)$. Figure 1 (a) shows the price of equity as a function of leverage for 'value' firms (earnings growth $=0$ ) and 'growth' firms (earnings growth $=0.3$ ). Figure $1(\mathrm{~b})$ shows the price of equity as a function of expected earnings growth for firms with high (earnings growth volatility $=0.75$ ) and low (earnings growth volatility $=0.05)$ levels of earnings growth volatility. 


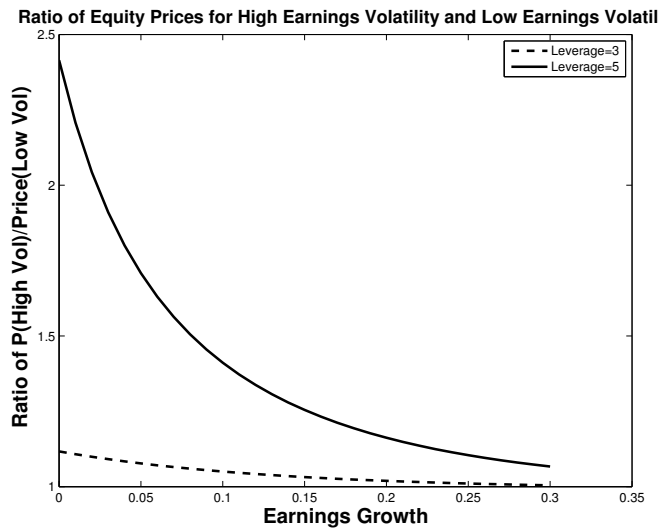

(a) The relative price of equity and leverage

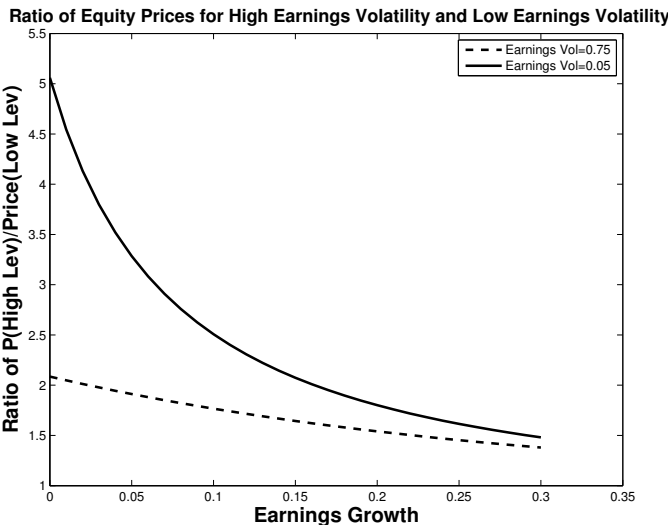

(b) The relative price of equity and earnings growth volatility

Fig. 2. The figure illustrates the relationships between the relative price of equity, leverage, expected earnings growth and earnings growth volatility. Leverage is measured as the face value of debt $(K)$ relative to initial assets $\left(A_{0}\right)$. Figure $2(\mathrm{a})$ shows the relative price of equity between high and low earnings growth volatility firms as a function of future earnings growth for low (leverage $=3$ ) and high (leverage $=5$ ) leverage firms. Figure 2(b) shows the relative price of equity between high and low leverage firms as a function of expected earnings growth for firms with high (earnings growth volatility $=0.75$ ) and low (earnings growth volatility $=0.05)$ levels of earnings growth volatility. 


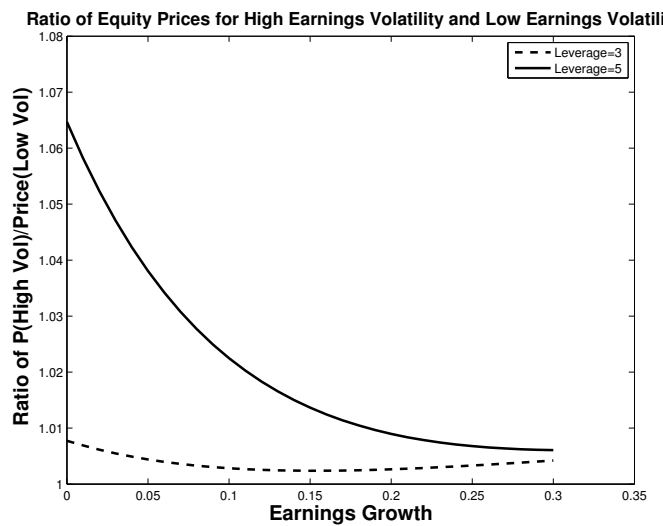

(a) The relative price of equity and leverage for debt maturity of ten years

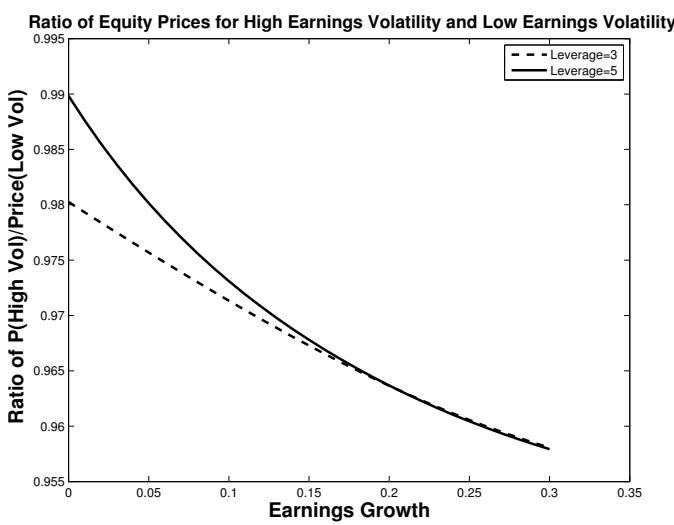

(b) The relative price of equity and leverage for debt maturity of fifteen years

Fig. 3. The figure illustrates the relationships between the relative price of equity, leverage, expected earnings growth and earnings growth volatility for different debt maturities. Leverage is measured as the face value of debt $(K)$ relative to initial assets $\left(A_{0}\right)$. Figure $3(\mathrm{a})$ shows the relative price of equity between high and low earnings growth volatility firms as a function of future earnings growth for low (leverage $=3$ ) and high (leverage $=5$ ) leverage firms with a debt maturity of 10 years. Figure $3(\mathrm{~b})$ shows the relative price of equity between high and low earnings growth volatility firms as a function of future earnings growth for low (leverage $=3$ ) and high (leverage $=5$ ) leverage firms with a debt maturity of 15 years. 
Financial and return characteristics of the sample firms over the period 1962-2013

\begin{tabular}{lrrrrrrr}
\hline textbfVariable & Mean & SD & Min & $25^{\text {th }}$ pct & Median & $75^{\text {th }}$ pct & Max \\
\hline Returns & 0.06 & 0.44 & -1.28 & -0.18 & 0.07 & 0.31 & 1.28 \\
Market Leverage & 0.21 & 0.22 & 0.00 & 0.02 & 0.15 & 0.36 & 0.81 \\
EP Ratio & 0.02 & 0.23 & -1.41 & 0.02 & 0.06 & 0.10 & 0.35 \\
BM Ratio & 1.23 & 2.71 & -0.22 & 0.37 & 0.69 & 1.19 & 23.70 \\
EGVOL & 1.11 & 2.74 & 0.02 & 0.13 & 0.29 & 0.78 & 20.34 \\
Asset Beta & 0.93 & 0.46 & 0.12 & 0.61 & 0.87 & 1.17 & 2.41 \\
Market Value (\$bil) & 1.22 & 3.64 & 0.002 & 0.034 & 0.147 & 0.681 & 26.735 \\
Accruals & -0.03 & 0.08 & -0.30 & -0.07 & -0.03 & 0.01 & 0.23 \\
Capital Investment & 0.01 & 0.08 & -0.29 & -0.00 & 0.00 & 0.00 & 0.60 \\
Net Operating Assets & 0.68 & 0.27 & -0.06 & 0.55 & 0.70 & 0.83 & 1.63 \\
Issuance & 0.10 & 0.23 & -0.35 & -0.00 & 0.03 & 0.15 & 1.19 \\
Asset Growth & 0.13 & 0.30 & -0.41 & -0.00 & 0.08 & 0.19 & 1.76 \\
Lag of Asset Growth & 0.15 & 0.32 & -0.40 & 0.00 & 0.09 & 0.20 & 1.88 \\
6-m BH Return & 0.14 & 0.39 & -0.57 & -0.09 & 0.08 & 0.28 & 1.80 \\
36-m BH Return & 0.57 & 1.25 & -0.87 & -0.20 & 0.27 & 0.91 & 6.64 \\
\hline
\end{tabular}

Table 1

The table presents financial and return characteristics of the sample firms over the period 1962-2013. We measure firm returns using the monthly holding period returns (variable name RET) from Compustat, which account for dividends and stock splits, annualised from July in year $t$ to June in year $(t+1)$. The other variables are defined as follows (with Compustat item names in parentheses). Market Leverage, as used in Titman, Wei, and Xie (2004). It is defined as long-term debt/(long-term debt + market value of equity) $\left[(\mathrm{DLTT}) /\left(\mathrm{DLTT}+\mathrm{PRCC} \_\mathrm{F}^{*} \mathrm{CSHO}\right)\right]$. The earnings-to-price ratio (EP Ratio) is [EPS (EPSPI)/ Price (PRCC_C)]. The book-to-market ratio (BM Ratio) for the fiscal year ending in calendar year $t$, is defined as in Davis, Fama, and French (2000), where book equity is the stockholders' equity (SEQ), plus balance sheet deferred taxes and investment tax credit (TXDITC), minus book value of preferred stock (in the following order: PSTKRV or PSTKL or PSTK) and market equity is the price times shares outstanding at the end of December of calendar year $t$. We define total future earnings growth volatility (EGVOL) as the standard deviation of the first difference in actual earnings that are measured between the end of year $t$ and $t+3$. Asset beta is the firm's asset beta (de-levered equity beta), where equity beta is estimated by regressing each individual firm's monthly excess returns on the monthly risk premium of the market over five years prior to the observation year. Market value is the price per share (PRCC_C) times shares outstanding (CSHO) at the end of June of calendar year $t$. Accruals $=[($ change in current assets - change in cash $)-($ change in current liabilities - change in short-term debt - change in taxes payable) - depreciation expense]/average total assets $):[(\Delta \mathrm{ACT}-\Delta \mathrm{CHE})-(\Delta \mathrm{LCT}-\Delta \mathrm{DLC}-\Delta \mathrm{TXP})-\mathrm{DP}] /\left[\left(\mathrm{AT}_{t}+\mathrm{AT}_{t-1}\right) / 2\right]$. Capital investment is the abnormal capital investment measure used in Titman, Wei, and Xie (2004). $\left[\mathrm{CE}_{t} /\left(\mathrm{CE}_{t-1}+\mathrm{CE}_{t-2}\right.\right.$ $\left.\left.+\mathrm{CE}_{t-3}\right) / 3-1\right]$, where $\mathrm{CE}_{t}$ is capital expenditures (CAPX) in fiscal year $t$ and each capital expenditure term is scaled by that year $t$ net sales (SALE). Net operating assets, as in Hirshleifer, Hou, Teoh, and Zhang (2004), is net operating assets scaled by lagged total assets. Net operating assets is the difference between operating assets (OA) and operating liabilities (OL), where OA = total assets (AT) - cash and short-term investments (CHE), and OL = total assets (AT) - debt in current liabilities (DLC) - long-term debt (DLTT) - minority interest (MIB) - preferred stock (PSTK) - common equity (CEQ). Issuance, as used in Daniel and Titman (2006), is $\log \left[\mathrm{ME}_{t} / \mathrm{ME}_{t-3}\right]-\mathrm{r}_{(t, t-3)}$ where ME is total market equity $=\left(\mathrm{PRCC}_{-} \mathrm{F}^{*} \mathrm{CSHO}\right)$ and $\mathrm{r}_{(t, t-3)}$ is the 3-year log return. Asset growth is the 1-year percentage change in total firm assets [(assets $t$ $\left.\operatorname{assets}_{t-1}\right) /$ assets $\left._{t-1}\right]$, where assets are Compustat item name (AT) as in Cooper, Gulen, and Schill (2008). To compute asset growth, a firm must have nonzero total assets in both years, $t-1$ and $t$-2. The lag of asset growth is the 1-year lagged value of asset growth. The calculation of buy-and-hold returns follows DeBondt and Thaler (1985); Jegadeesh and Titman (1993). The 6-month buy-and-hold return (6-m. BH Return) is calculated over January $(t)$ to June $(t)\left[\left(1+\mathrm{r}_{1}\right) \times \ldots \times\left(1+\mathrm{r}_{6}\right)-1\right]$ where $\mathrm{r}_{i}$ is the return in month $i$. The 36-month buy-and-hold return (36-m. BH Return) is calculated over July $(t-3)$ to June $(t)\left[\left(1+\mathrm{r}_{1}\right) \mathrm{x} \ldots \mathrm{x}\right.$ $\left(1+\mathrm{r}_{36}\right)-1$ ] where $\mathrm{r}_{i}$ is the return in month $i$. Significance is indicated as follows: $* * * \mathrm{p}<0.01, * * \mathrm{p}<0.05, *$ $\mathrm{p}<0.10$. 


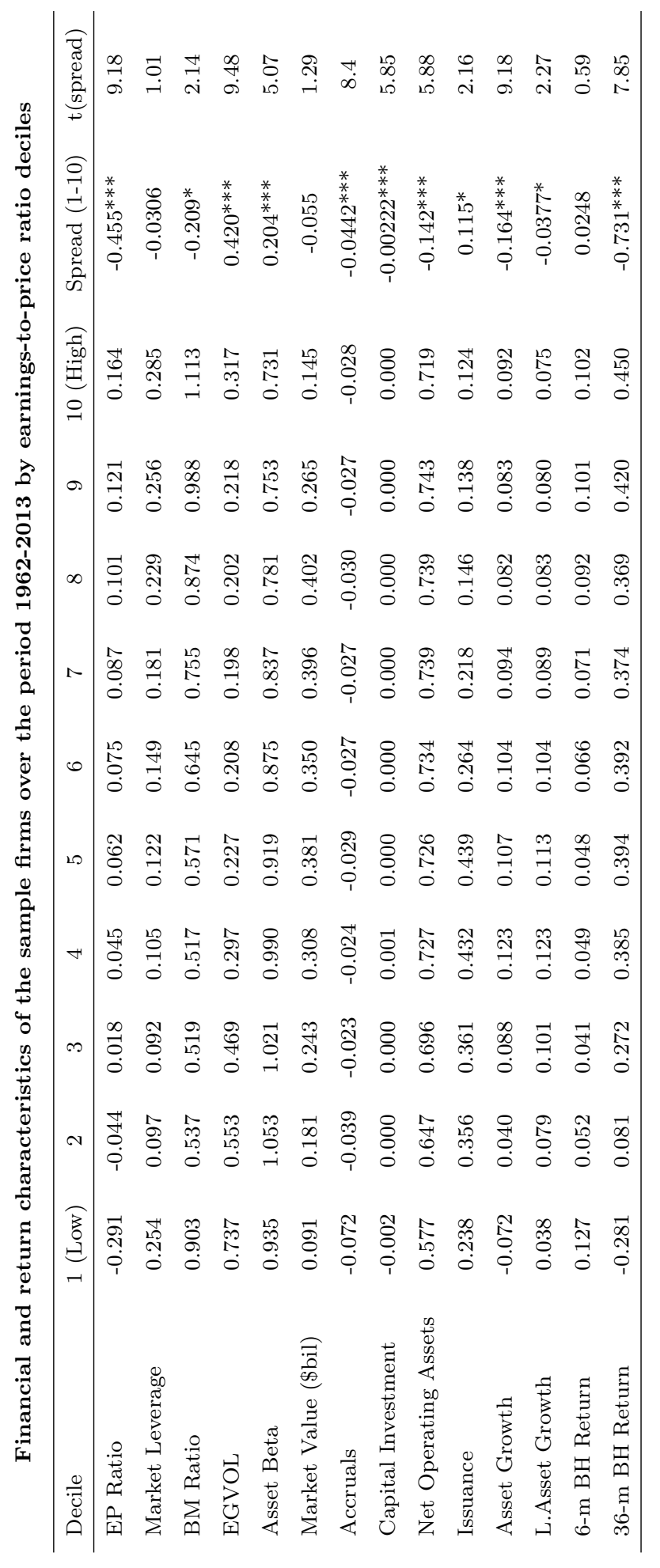

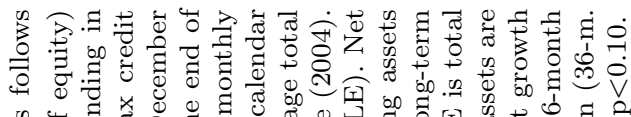

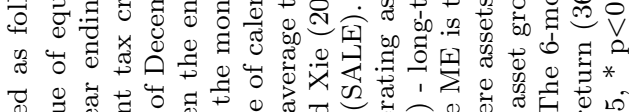

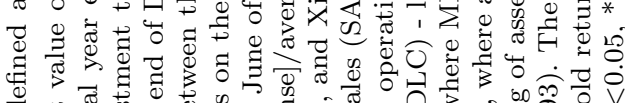

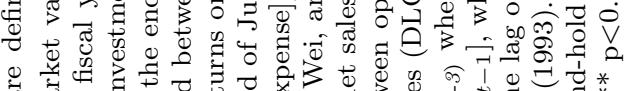

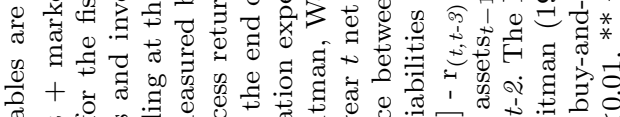

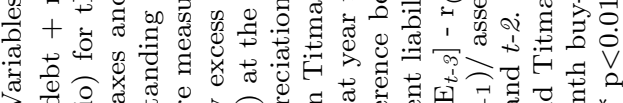

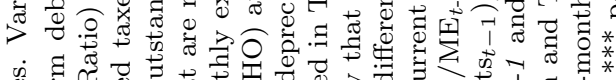

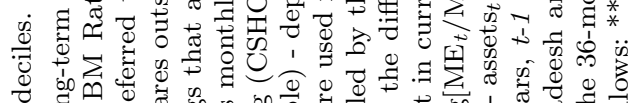
으의.

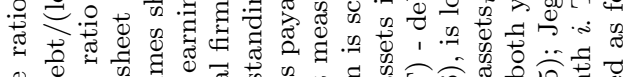

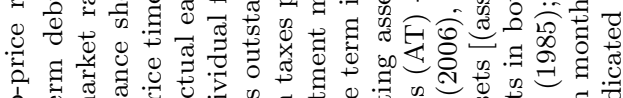
S 政故

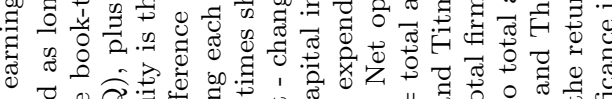

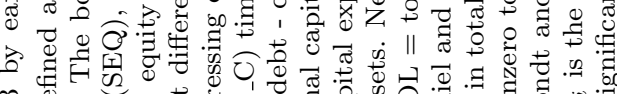

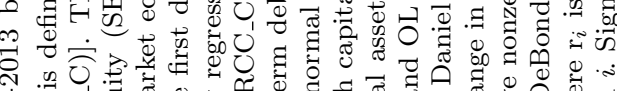

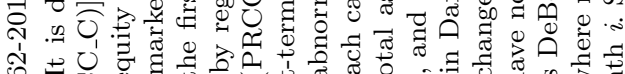

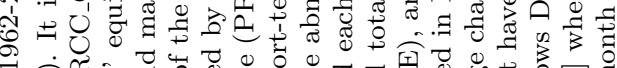

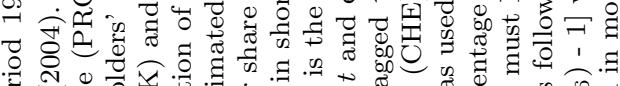

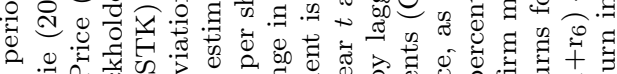

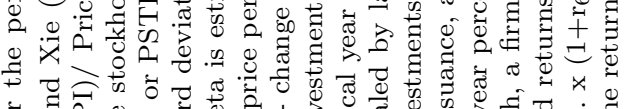

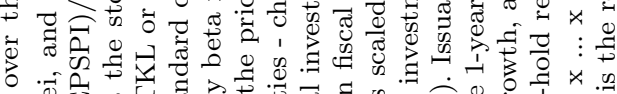
等

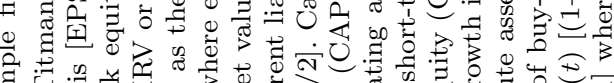

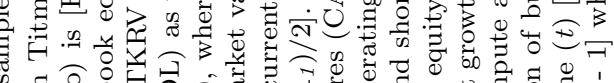

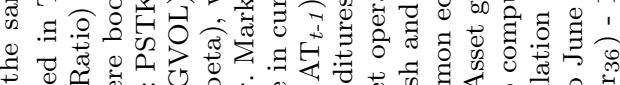

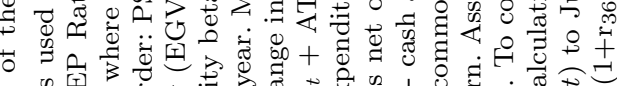

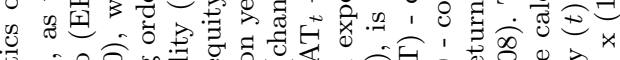

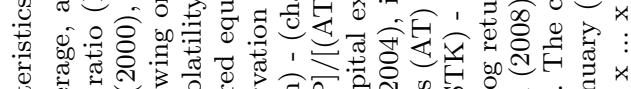

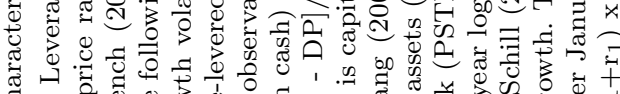

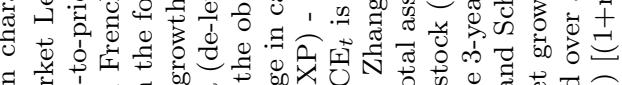

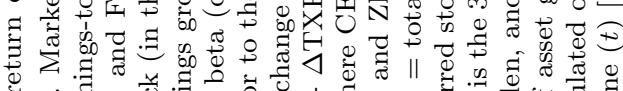

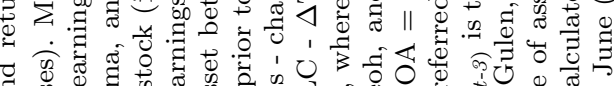

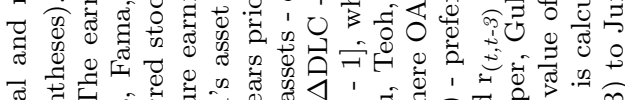

즌

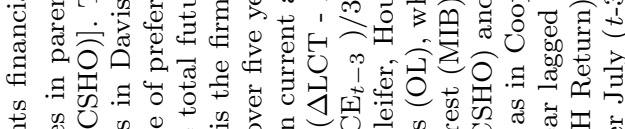

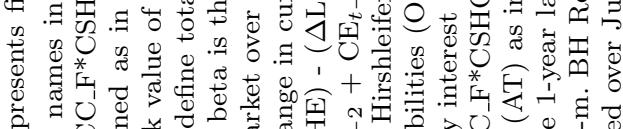

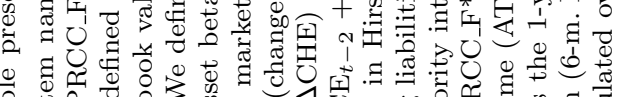

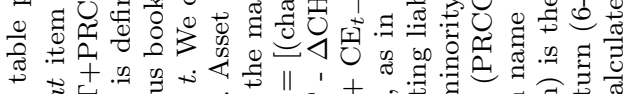

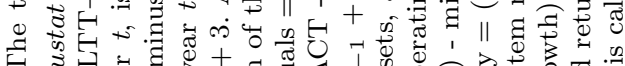

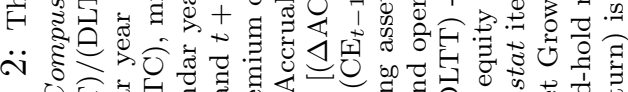
O

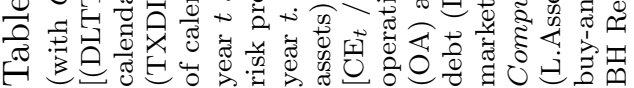




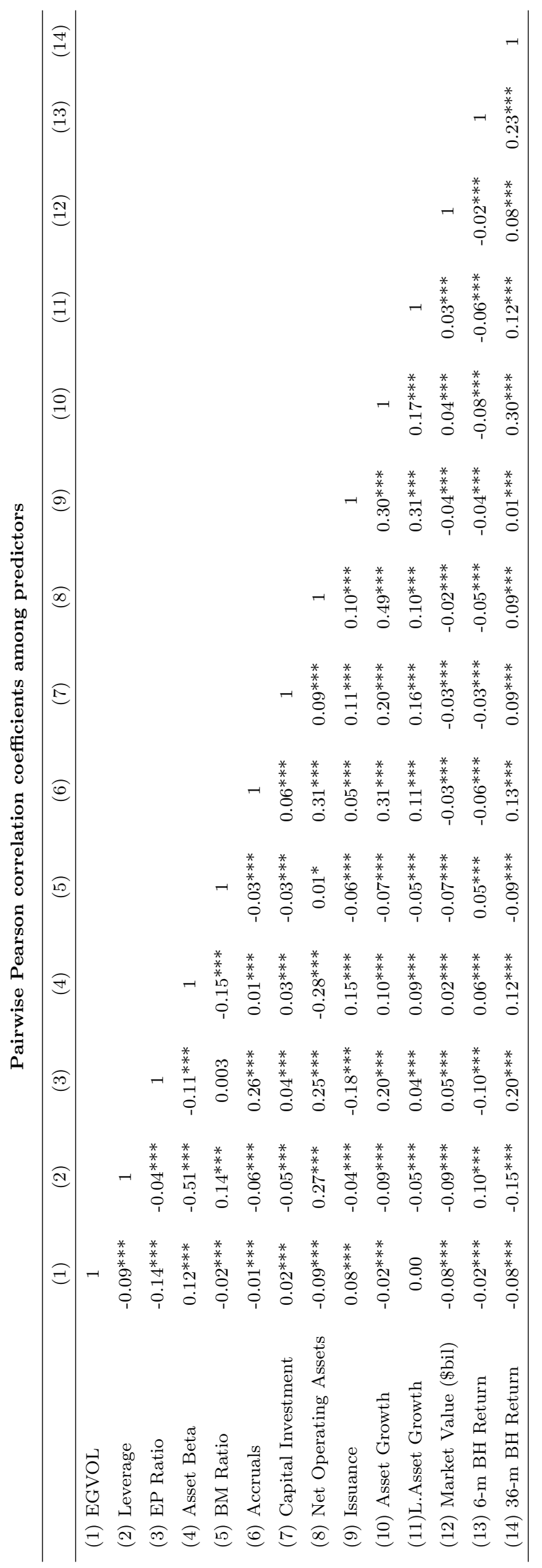

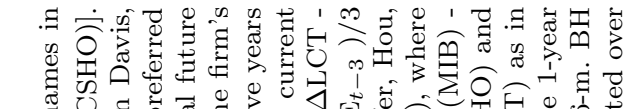

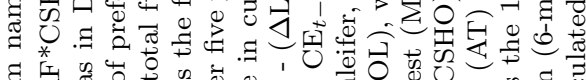

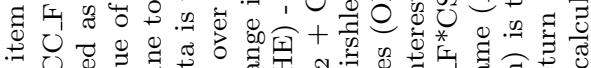

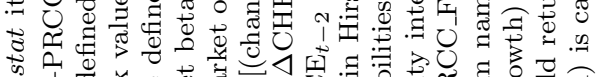

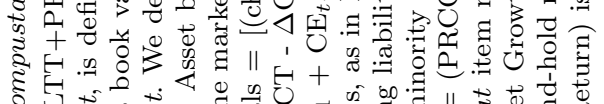

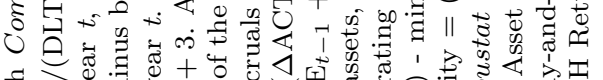

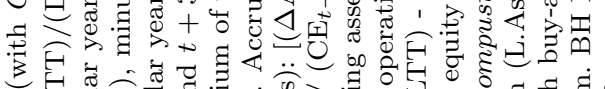

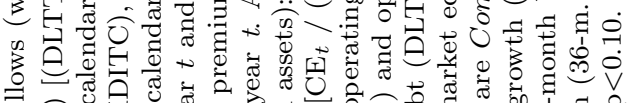

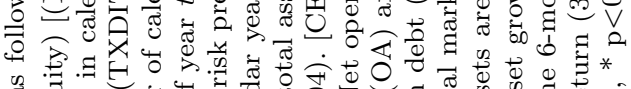
势

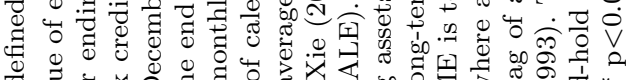

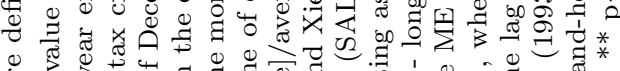

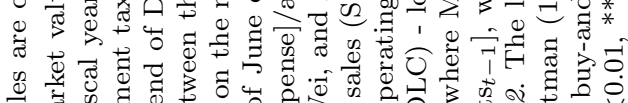

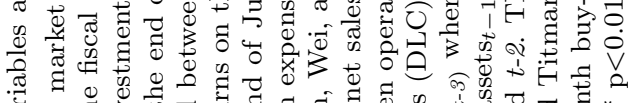

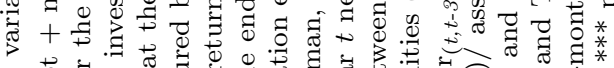

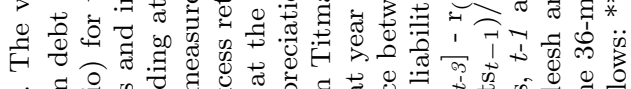

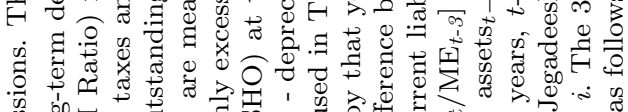
W

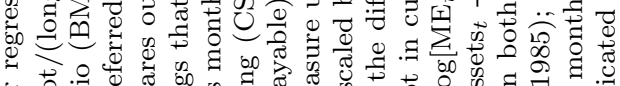

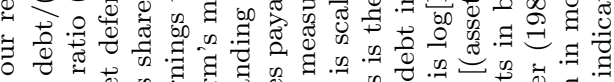

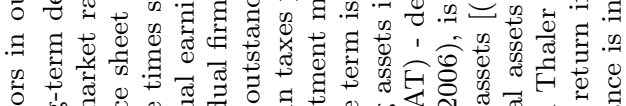

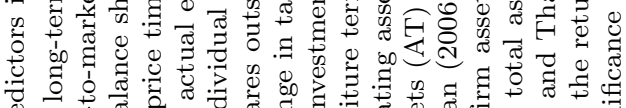

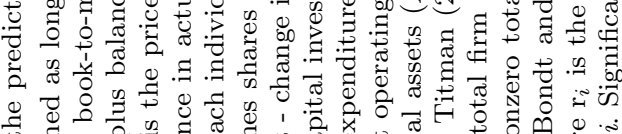

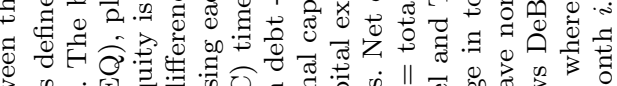

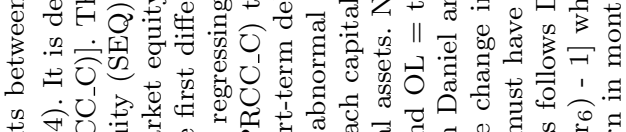

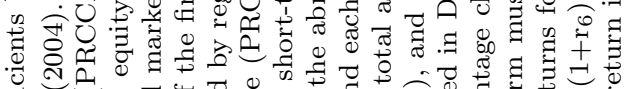

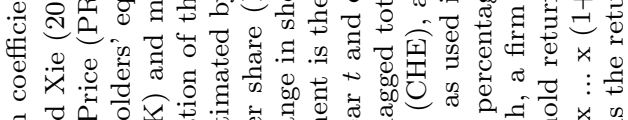

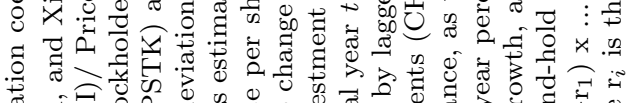

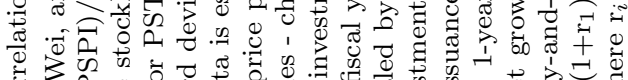

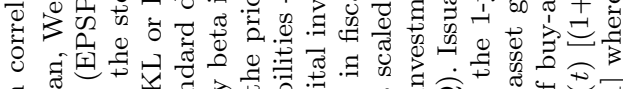

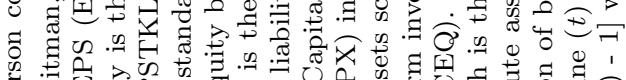

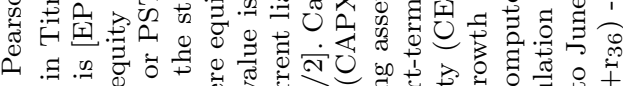

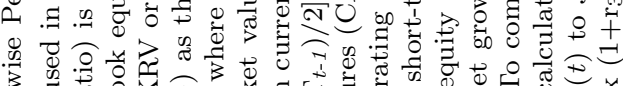

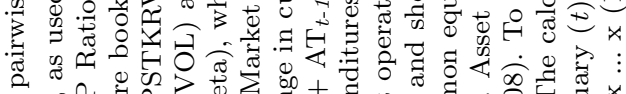

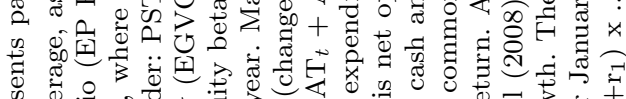

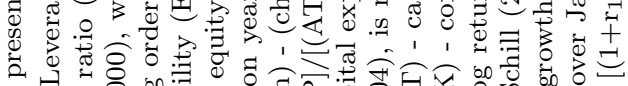

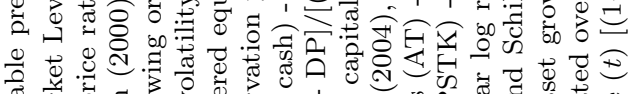

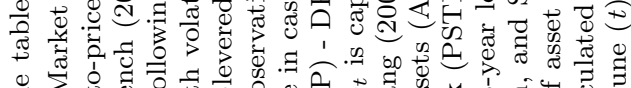

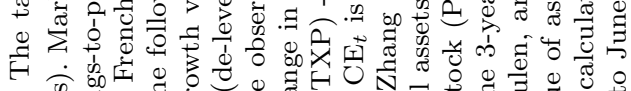

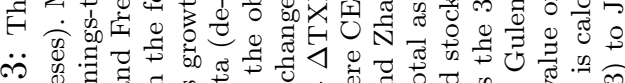

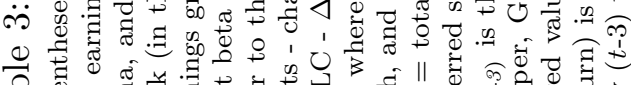

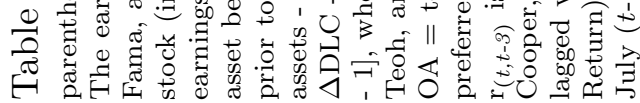


Results for actual and expected total future earnings growth volatility (EGVOL)

\begin{tabular}{|c|c|c|c|c|}
\hline Dependent variable: Firm returns $t+1$ & (1) & (2) & (3) & (4) \\
\hline EGVOL measure employed: & Total EGV & $\operatorname{AR}(1)$ & $\operatorname{AR}(3)$ & $\operatorname{AR}(5)$ \\
\hline Leverage x Low Growth Dummy (+) & $\begin{array}{l}0.0645^{* * *} \\
(0.01)\end{array}$ & $\begin{array}{c}0.0624 \\
(0.04)\end{array}$ & $\begin{array}{c}0.0702 \\
(0.04)\end{array}$ & $\begin{array}{c}0.0726 \\
(0.05)\end{array}$ \\
\hline EGVOL (-) & $\begin{array}{c}-0.0106^{* * *} \\
(0.00)\end{array}$ & $\begin{array}{l}-0.0220^{* * *} \\
(0.01)\end{array}$ & $\begin{array}{c}-0.0237^{* *} \\
(0.01)\end{array}$ & $\begin{array}{c}-0.0247^{* * *} \\
(0.01)\end{array}$ \\
\hline EGVOL x Low Growth Dummy (-) & $\begin{array}{c}-0.0073^{* * *} \\
(0.00)\end{array}$ & $\begin{array}{c}0.0038 \\
(0.01)\end{array}$ & $\begin{array}{c}0.0012 \\
(0.01)\end{array}$ & $\begin{array}{c}0.0020 \\
(0.01)\end{array}$ \\
\hline Market Leverage & $\begin{array}{c}0.1240 * * * \\
(0.01)\end{array}$ & $\begin{array}{c}0.0843^{* *} \\
(0.04)\end{array}$ & $\begin{array}{c}0.0670 \\
(0.04)\end{array}$ & $\begin{array}{c}0.0709 \\
(0.05)\end{array}$ \\
\hline Earnings-to-price Ratio & $\begin{array}{c}0.0239^{* *} \\
(0.01)\end{array}$ & $\begin{array}{c}0.0234^{*} \\
(0.01)\end{array}$ & $\begin{array}{l}0.0415^{* * *} \\
(0.02)\end{array}$ & $\begin{array}{l}0.0512^{* * *} \\
(0.02)\end{array}$ \\
\hline Book-to-market equity & $\begin{array}{c}0.0055^{* * * *} \\
\quad(0.00)\end{array}$ & $\begin{array}{c}0.0063^{* * * *} \\
(0.00)\end{array}$ & $\begin{array}{c}0.0069^{* * * *} \\
(0.00)\end{array}$ & $\begin{array}{c}0.0083^{* * * *} \\
(0.00)\end{array}$ \\
\hline Asset Beta & $\begin{array}{c}0.0305^{* * *} \\
(0.01)\end{array}$ & $\begin{array}{c}0.0376^{* * * *} \\
(0.01)\end{array}$ & $\begin{array}{c}0.0384^{* * *} \\
(0.01)\end{array}$ & $\begin{array}{c}0.0520^{* * *} \\
(0.01)\end{array}$ \\
\hline ACCRUALS & $\begin{array}{c}-0.0145 \\
(0.03)\end{array}$ & $\begin{array}{c}-0.0196 \\
(0.03)\end{array}$ & $\begin{array}{c}-0.0078 \\
(0.03)\end{array}$ & $\begin{array}{c}0.0049 \\
(0.04)\end{array}$ \\
\hline Capital Expenditure & $\begin{array}{c}-0.0160 \\
(0.03)\end{array}$ & $\begin{array}{c}-0.0235 \\
(0.04)\end{array}$ & $\begin{array}{c}-0.0436 \\
(0.06)\end{array}$ & $\begin{array}{c}-0.0254 \\
(0.08)\end{array}$ \\
\hline Net Operating Assets & $\begin{array}{c}0.0177^{*} \\
(0.01)\end{array}$ & $\begin{array}{c}0.0080 \\
(0.01)\end{array}$ & $\begin{array}{c}0.0279 * * \\
(0.01)\end{array}$ & $\begin{array}{c}0.0160 \\
(0.01)\end{array}$ \\
\hline Issuance & $\begin{array}{c}-0.1171^{* * *} \\
(0.01)\end{array}$ & $\begin{array}{c}-0.0974^{* * *} \\
(0.01)\end{array}$ & $\begin{array}{c}-0.0850^{* * *} \\
(0.01)\end{array}$ & $\begin{array}{c}-0.0748^{* * *} \\
(0.01)\end{array}$ \\
\hline Asset Growth & $\begin{array}{c}-0.0928^{* * *} \\
(0.01)\end{array}$ & $\begin{array}{c}-0.0843^{* * *} \\
(0.01)\end{array}$ & $\begin{array}{l}-0.1043^{* * *} \\
(0.01)\end{array}$ & $\begin{array}{c}-0.1045^{* * *} \\
(0.02)\end{array}$ \\
\hline Lag of Asset Growth & $\begin{array}{c}-0.0269^{* * *} \\
(0.01)\end{array}$ & $\begin{array}{c}-0.0285^{* * *} \\
(0.01)\end{array}$ & $\begin{array}{c}-0.0442^{* * *} \\
(0.01)\end{array}$ & $\begin{array}{c}-0.0482^{* * * *} \\
(0.01)\end{array}$ \\
\hline Market Value (Bil) & $\begin{array}{c}-0.0024^{* * *} \\
(0.00)\end{array}$ & $\begin{array}{c}-0.0028^{* * *} \\
(0.00)\end{array}$ & $\begin{array}{l}-0.0033^{* * *} \\
(0.00)\end{array}$ & $\begin{array}{l}-0.0030^{* * *} \\
(0.00)\end{array}$ \\
\hline 6-month BHRET & $\begin{array}{c}-0.0009 \\
(0.01)\end{array}$ & $\begin{array}{c}-0.0032 \\
(0.01)\end{array}$ & $\begin{array}{c}-0.0149 * * \\
(0.01)\end{array}$ & $\begin{array}{c}-0.0230^{* * * *} \\
(0.01)\end{array}$ \\
\hline 36-month BHRET & $\begin{array}{l}-0.0173^{* * *} \\
(0.00)\end{array}$ & $\begin{array}{c}-0.0177^{* * *} \\
(0.00)\end{array}$ & $\begin{array}{c}-0.0186^{* * * *} \\
(0.00)\end{array}$ & $\begin{array}{c}-0.0160^{* * * *} \\
(0.00)\end{array}$ \\
\hline Constant & $\begin{array}{c}0.0330^{* * * *} \\
\quad(0.01)\end{array}$ & $\begin{array}{c}0.0436^{* * *} \\
\quad(0.01)\end{array}$ & $\begin{array}{l}0.0444^{* * * *} \\
\quad(0.01)\end{array}$ & $\begin{array}{c}0.0352^{* * *} \\
\quad(0.01)\end{array}$ \\
\hline Observations & 63,959 & 53,172 & 43,297 & 34,393 \\
\hline
\end{tabular}

Table 4

The table presents the main regression results for the sample firms estimated as a pooled OLS regression over the period 1962-2013. All variables are defined as in Table 1. Independent variables are lagged by one year in order to employ only information that is available when investors form expectations about returns in year $t+1$. Specification (1) employs actual future earnings growth volatility, defined as the standard deviation of the first difference in actual earnings that are measured between the end of year $t$ and $t+3$. Specifications (2) to (4) employ expected future future earnings growth volatility from autoregressive models with different lag structures, using non-overlapping observations. Robust standard errors, clustered by firm, are shown in parentheses. Predicted signs for the main variables of interest are also shown in parentheses. Significance is indicated as follows: *** $\mathrm{p}<0.01,{ }^{* *} \mathrm{p}<0.05,{ }^{*} \mathrm{p}<0.10$. 
Results for systematic and idiosyncratic future earnings growth volatility (EGVOL)

\begin{tabular}{|c|c|c|}
\hline & $(1)$ & $(2)$ \\
\hline VARIABLES & Macro & Idio - Direct EPS \\
\hline Dependent variable: Firm returns $t+1$ & $(1)$ & $(2)$ \\
\hline Volatility measure employed: & Macroeconomic volatility & Dispersion \\
\hline Systematic EGVOL (-) & $\begin{array}{c}-0.0995^{* * *} \\
(0.02)\end{array}$ & $\begin{array}{c}-0.0112 \\
(0.04)\end{array}$ \\
\hline Systematic EGVOL x Low Growth Dummy (-) & $\begin{array}{c}0.0842^{* * *} \\
(0.01)\end{array}$ & $\begin{array}{c}-0.0034 \\
(0.03)\end{array}$ \\
\hline Idiosyncratic EGVOL (-) & $\begin{array}{c}-0.0011 \\
(0.00)\end{array}$ & $\begin{array}{c}-0.2714^{* * *} \\
(0.08)\end{array}$ \\
\hline Idiosyncratic EGVOL x Low Growth Dummy (-) & $\begin{array}{c}-0.0114^{* *} \\
(0.00)\end{array}$ & $\begin{array}{c}0.0721 \\
(0.08)\end{array}$ \\
\hline tab:corr Market Leverage & $\begin{array}{c}0.1535^{* * *} \\
(0.01)\end{array}$ & $\begin{array}{c}0.1349 * * * \\
(0.02)\end{array}$ \\
\hline Earnings-to-price Ratio & $\begin{array}{c}0.0196^{*} \\
(0.01)\end{array}$ & $\begin{array}{c}-0.0329 \\
(0.03)\end{array}$ \\
\hline Book-to-market equity & $\begin{array}{c}0.0050^{* * *} \\
(0.00)\end{array}$ & $\begin{array}{c}0.0235^{* * *} \\
(0.00)\end{array}$ \\
\hline Asset Beta & $\begin{array}{c}0.0313^{* * *} \\
(0.01)\end{array}$ & $\begin{array}{c}0.0261 * * * \\
(0.01)\end{array}$ \\
\hline ACCRUALS & $\begin{array}{c}-0.0155 \\
(0.03)\end{array}$ & $\begin{array}{c}-0.0339 \\
(0.05)\end{array}$ \\
\hline Capital Expenditure & $\begin{array}{c}-0.0130 \\
(0.03)\end{array}$ & $\begin{array}{c}-0.2727^{* *} \\
(0.12)\end{array}$ \\
\hline Net Operating Assets & $\begin{array}{c}0.0046 \\
(0.01)\end{array}$ & $\begin{array}{c}0.0347^{* *} \\
(0.02)\end{array}$ \\
\hline Issuance & $\begin{array}{c}-0.1101^{* * * *} \\
(0.01)\end{array}$ & $\begin{array}{c}-0.0902^{* * *} \\
(0.02)\end{array}$ \\
\hline Asset Growth & $\begin{array}{c}-0.0897^{* * *} \\
(0.01)\end{array}$ & $\begin{array}{c}-0.1004^{* * *} \\
(0.02)\end{array}$ \\
\hline Lag of Asset Growth & $\begin{array}{c}-0.0295^{* * * *} \\
(0.01)\end{array}$ & $\begin{array}{c}-0.0234^{*} \\
(0.01)\end{array}$ \\
\hline Market Value (Bil) & $\begin{array}{c}-0.0023^{* * *} \\
(0.00)\end{array}$ & $\begin{array}{c}-0.0007 \\
(0.00)\end{array}$ \\
\hline 6-month BHRET & $\begin{array}{c}-0.0013 \\
(0.01)\end{array}$ & $\begin{array}{c}0.0064 \\
(0.01)\end{array}$ \\
\hline 36-month BHRET & $\begin{array}{c}-0.0162^{* * * *} \\
(0.00)\end{array}$ & $\begin{array}{c}-0.0202^{* * *} \\
(0.00)\end{array}$ \\
\hline Constant & $\begin{array}{c}0.0448^{* *} \\
(0.02)\end{array}$ & $\begin{array}{c}0.0502 \\
(0.04)\end{array}$ \\
\hline Observations & 63,959 & 19,422 \\
\hline
\end{tabular}

Table 5

The table presents the additional regression results for the sample firms estimated as a pooled OLS regression over the period 1962-2013. All variables are defined as in Table 1. Independent variables are lagged by one year in order to employ only information that is available when investors form expectations about returns in year $t+1$. Specification (1) employs systematic future earnings growth volatility, defined as the predicted value from firm-level projections of total actual future earnings growth volatility on macroeconomic volatility, and idiosyncratic future earnings growth volatility, defined as the residual from these projections. Specification (2) employs replaces idiosyncratic future earnings growth volatility with the measure obtained from the dispersion of analyst earnings forecasts. Robust standard errors, clustered by firm, are shown in parentheses. Predicted signs for the main variables of interest are also shown in parentheses. Significance is indicated as follows: *** $\mathrm{p}<0.01, * * \mathrm{p}<0.05, * \mathrm{p}<0.10$. 
Results for total future earnings growth volatility (EGVOL) with different cut-off for the low growth indicator

\begin{tabular}{|c|c|c|c|}
\hline & (1) & $(2)$ & $(3)$ \\
\hline Dependent variable: Firm returns $t+1$ & Total EGV & Total EGV & Total EGV \\
\hline Low Growth Indicator: EP cut-off points & $25 \%$ & $33 \%$ & $50 \%$ \\
\hline Leverage x Low Growth Dummy (+) & $\begin{array}{c}0.0645^{* * *} \\
(0.01)\end{array}$ & $\begin{array}{c}0.0730 * * * \\
(0.01)\end{array}$ & $\begin{array}{c}0.0886 * * * \\
(0.01)\end{array}$ \\
\hline EGVOL (-) & $\begin{array}{c}-0.0106^{* * *} \\
(0.00)\end{array}$ & $\begin{array}{c}-0.0101^{* * *} \\
(0.00)\end{array}$ & $\begin{array}{c}-0.0086^{* * *} \\
(0.00)\end{array}$ \\
\hline EGVOL * Low Growth Dummy (-) & $\begin{array}{c}-0.0073^{* * *} \\
(0.00)\end{array}$ & $\begin{array}{c}-0.0079 * * * \\
(0.00)\end{array}$ & $\begin{array}{c}-0.0095^{* * *} \\
(0.00)\end{array}$ \\
\hline Market Leverage & $\begin{array}{c}0.1240 * * * \\
(0.01)\end{array}$ & $\begin{array}{c}0.1164 * * * \\
(0.01)\end{array}$ & $\begin{array}{c}0.1012^{* * *} \\
(0.01)\end{array}$ \\
\hline Earnings-to-price Ratio & $\begin{array}{c}0.0239 * * \\
(0.01)\end{array}$ & $\begin{array}{c}0.0215^{*} \\
(0.01)\end{array}$ & $\begin{array}{c}0.0177 \\
(0.01)\end{array}$ \\
\hline Book-to-market equity & $\begin{array}{c}0.0055^{* * *} \\
(0.00)\end{array}$ & $\begin{array}{c}0.0055^{* * * *} \\
(0.00)\end{array}$ & $\begin{array}{c}0.0055^{* * *} \\
(0.00)\end{array}$ \\
\hline Asset Beta & $\begin{array}{c}0.0305^{* * * *} \\
(0.01)\end{array}$ & $\begin{array}{c}0.0305^{* * *} \\
(0.01)\end{array}$ & $\begin{array}{c}0.0306^{* * *} \\
(0.01)\end{array}$ \\
\hline ACCRUALS & $\begin{array}{c}-0.0145 \\
(0.03)\end{array}$ & $\begin{array}{c}-0.0144 \\
(0.03)\end{array}$ & $\begin{array}{c}-0.0118 \\
(0.03)\end{array}$ \\
\hline Capital Expenditure & $\begin{array}{c}-0.0160 \\
(0.03)\end{array}$ & $\begin{array}{c}-0.0159 \\
(0.03)\end{array}$ & $\begin{array}{c}-0.0162 \\
(0.03)\end{array}$ \\
\hline Net Operating Assets & $\begin{array}{c}0.0177^{*} \\
(0.01)\end{array}$ & $\begin{array}{c}0.0177^{*} \\
(0.01)\end{array}$ & $\begin{array}{c}0.0164^{*} \\
(0.01)\end{array}$ \\
\hline Issuance & $\begin{array}{c}-0.1171^{* * *} \\
(0.01)\end{array}$ & $\begin{array}{c}-0.1175^{* * * *} \\
(0.01)\end{array}$ & $\begin{array}{c}-0.1184^{* * * *} \\
(0.01)\end{array}$ \\
\hline Asset Growth & $\begin{array}{c}-0.0928^{* * *} \\
(0.01)\end{array}$ & $\begin{array}{c}-0.0924^{* * *} \\
(0.01)\end{array}$ & $\begin{array}{c}-0.0914^{* * *} \\
(0.01)\end{array}$ \\
\hline Lag of Asset Growth & $\begin{array}{c}-0.0269^{* * *} \\
(0.01)\end{array}$ & $\begin{array}{c}-0.0266^{* * *} \\
(0.01)\end{array}$ & $\begin{array}{c}-0.0260^{* * *} \\
(0.01)\end{array}$ \\
\hline Market Value in Bils & $\begin{array}{c}-0.0024^{* * * *} \\
(0.00)\end{array}$ & $\begin{array}{c}-0.0024^{* * *} \\
(0.00)\end{array}$ & $\begin{array}{c}-0.0024^{* * *} \\
(0.00)\end{array}$ \\
\hline 6-month BHRET & $\begin{array}{c}-0.0009 \\
(0.01)\end{array}$ & $\begin{array}{c}-0.0010 \\
(0.01)\end{array}$ & $\begin{array}{c}-0.0013 \\
(0.01)\end{array}$ \\
\hline 36-month BHRET & $\begin{array}{c}-0.0173^{* * *} \\
(0.00)\end{array}$ & $\begin{array}{c}-0.0173^{* * *} \\
(0.00)\end{array}$ & $\begin{array}{c}-0.0172^{* * *} \\
(0.00)\end{array}$ \\
\hline Constant & $\begin{array}{c}0.0330 * * * \\
(0.01)\end{array}$ & $\begin{array}{c}0.0330 * * * \\
(0.01)\end{array}$ & $\begin{array}{c}0.0332^{* * *} \\
(0.01)\end{array}$ \\
\hline Observations & 63,959 & 63,959 & 63,959 \\
\hline
\end{tabular}

Table 6

The table presents the main regression results for the sample firms estimated as a pooled OLS regression over the period 1962-2013. All variables are defined as in Table 1. Independent variables are lagged by one year in order to employ only information that is available when investors form expectations about returns in year $t+1$. The regressions employ actual future earnings growth volatility, defined as the standard deviation of the first difference in actual earnings that are measured between the end of year $t$ and $t+3$. Robust standard errors, clustered by firm, are shown in parentheses. Predicted signs for the main variables of interest are also shown in parentheses. Significance is indicated as follows: $* * * \mathrm{p}<0.01,{ }^{* *} \mathrm{p}<0.05,{ }^{*} \mathrm{p}<0.10$. 
Results for total future earnings growth volatility (EGVOL) with additional control variables

\begin{tabular}{|c|c|c|c|c|c|}
\hline Dependent variable: Firm returns $t+1$ & (1) & $(2)$ & (3) & (4) & $(5)$ \\
\hline Additional control variables & Div Yield & Z-Score & Leverage $^{2}$ & $\mathrm{SIC} 2 \mathrm{~d} \mathrm{FE}$ & SIC2d year FE \\
\hline Leverage x Low Growth (+) & $\begin{array}{c}0.0692^{* * *} \\
(0.01)\end{array}$ & $\begin{array}{c}0.0556^{* * *} \\
(0.01)\end{array}$ & $\begin{array}{c}0.0640^{* * *} \\
(0.01)\end{array}$ & $\begin{array}{c}0.0676^{* * *} \\
(0.01)\end{array}$ & $\begin{array}{c}0.0777^{* * * *} \\
(0.01)\end{array}$ \\
\hline EGVOL (-) & $\begin{array}{c}-0.0100^{* * *} \\
(0.00)\end{array}$ & $\begin{array}{c}-0.0112^{* * *} \\
(0.00)\end{array}$ & $\begin{array}{c}-0.0106 * * * \\
(0.00)\end{array}$ & $\begin{array}{c}-0.0105^{* * *} \\
(0.00)\end{array}$ & $\begin{array}{c}-0.0103^{* * *} \\
(0.00)\end{array}$ \\
\hline EGVOL * Low Growth Dummy (-) & $\begin{array}{c}-0.0070^{* * *} \\
(0.00)\end{array}$ & $\begin{array}{c}-0.0073^{* * *} \\
(0.00)\end{array}$ & $\begin{array}{c}-0.0073^{* * *} \\
(0.00)\end{array}$ & $\begin{array}{c}-0.0071^{* * *} \\
(0.00)\end{array}$ & $\begin{array}{c}-0.0050^{* * * *} \\
(0.00)\end{array}$ \\
\hline Market Leverage & $\begin{array}{c}0.0931^{* * *} \\
(0.01)\end{array}$ & $\begin{array}{c}0.1364^{* * * *} \\
(0.01)\end{array}$ & $\begin{array}{c}0.1048^{* * * *} \\
(0.03)\end{array}$ & $\begin{array}{c}0.1248^{* * *} \\
(0.01)\end{array}$ & $\begin{array}{c}0.0607^{* * *} * \\
(0.01)\end{array}$ \\
\hline Earnings-to-price Ratio & $\begin{array}{c}0.0061 \\
(0.01)\end{array}$ & $\begin{array}{c}0.0357^{* * *} * \\
(0.01)\end{array}$ & $\begin{array}{c}0.0250^{* *} \\
(0.01)\end{array}$ & $\begin{array}{c}0.0187 \\
(0.01)\end{array}$ & $\begin{array}{c}-0.0075 \\
(0.01)\end{array}$ \\
\hline Book-to-market equity & $\begin{array}{c}0.0052^{* * *} \\
(0.00)\end{array}$ & $\begin{array}{c}0.0050 * * * \\
(0.00)\end{array}$ & $\begin{array}{c}0.0055 * * * \\
(0.00)\end{array}$ & $\begin{array}{c}0.0057^{* * *} \\
(0.00)\end{array}$ & $\begin{array}{c}0.0041 * * * \\
(0.00)\end{array}$ \\
\hline Asset Beta & $\begin{array}{c}0.0421^{* * *} \\
(0.01)\end{array}$ & $\begin{array}{c}0.0447 * * * \\
(0.01)\end{array}$ & $\begin{array}{c}0.0305^{* * *} \\
(0.01)\end{array}$ & $\begin{array}{c}0.0444^{* * *} \\
(0.01)\end{array}$ & $\begin{array}{c}0.0400^{* * *} \\
(0.01)\end{array}$ \\
\hline ACCRUALS & $\begin{array}{c}-0.0229 \\
(0.03)\end{array}$ & $\begin{array}{c}-0.0162 \\
(0.03)\end{array}$ & $\begin{array}{c}-0.0158 \\
(0.03)\end{array}$ & $\begin{array}{c}-0.0119 \\
(0.03)\end{array}$ & $\begin{array}{c}-0.0648^{* *} \\
(0.03)\end{array}$ \\
\hline Capital Expenditure & $\begin{array}{c}-0.0155 \\
(0.03)\end{array}$ & $\begin{array}{c}0.0317 \\
(0.04)\end{array}$ & $\begin{array}{c}-0.0163 \\
(0.03)\end{array}$ & $\begin{array}{c}-0.0188 \\
(0.03)\end{array}$ & $\begin{array}{c}-0.0420 \\
(0.03)\end{array}$ \\
\hline Net Operating Assets & $\begin{array}{c}0.0195^{* *} \\
(0.01)\end{array}$ & $\begin{array}{c}-0.0080 \\
(0.01)\end{array}$ & $\begin{array}{c}0.0191^{* *} \\
(0.01)\end{array}$ & $\begin{array}{c}0.0198^{* *} \\
(0.01)\end{array}$ & $\begin{array}{c}0.0230^{* *} \\
(0.01)\end{array}$ \\
\hline Issuance & $\begin{array}{c}-0.1204^{* * *} \\
(0.01)\end{array}$ & $\begin{array}{c}-0.1239^{* * *} \\
(0.01)\end{array}$ & $\begin{array}{c}-0.1171^{* * * *} \\
(0.01)\end{array}$ & $\begin{array}{c}-0.1258^{* * *} \\
(0.01)\end{array}$ & $\begin{array}{c}-0.1240^{* * *} \\
(0.01)\end{array}$ \\
\hline Asset Growth & $\begin{array}{c}-0.0847^{* * * *} \\
(0.01)\end{array}$ & $\begin{array}{c}-0.0726^{* * *} \\
(0.01)\end{array}$ & $\begin{array}{c}-0.0935^{* * *} \\
(0.01)\end{array}$ & $\begin{array}{c}-0.0929 * * * \\
(0.01)\end{array}$ & $\begin{array}{c}-0.0801^{* * * *} \\
(0.01)\end{array}$ \\
\hline Lag of Asset Growth & $\begin{array}{c}-0.0218^{* * *} \\
(0.01)\end{array}$ & $\begin{array}{c}-0.0286^{* * *} \\
(0.01)\end{array}$ & $\begin{array}{c}-0.0270^{* * *} \\
(0.01)\end{array}$ & $\begin{array}{c}-0.0262^{* * *} \\
(0.01)\end{array}$ & $\begin{array}{c}-0.0160 * * \\
(0.01)\end{array}$ \\
\hline Market Value in Bils & $\begin{array}{c}-0.0025^{* * *} \\
(0.00)\end{array}$ & $\begin{array}{c}-0.0024^{* * *} \\
(0.00)\end{array}$ & $\begin{array}{c}-0.0023^{* * *} \\
(0.00)\end{array}$ & $\begin{array}{c}-0.0028^{* * *} \\
(0.00)\end{array}$ & $\begin{array}{c}-0.0001 \\
(0.00)\end{array}$ \\
\hline 6-month BHRET & $\begin{array}{c}-0.0018 \\
(0.01)\end{array}$ & $\begin{array}{c}-0.0025 \\
(0.01)\end{array}$ & $\begin{array}{c}-0.0011 \\
(0.01)\end{array}$ & $\begin{array}{c}-0.0015 \\
(0.01)\end{array}$ & $\begin{array}{c}-0.0068 \\
(0.01)\end{array}$ \\
\hline 36-month BHRET & $\begin{array}{c}-0.0171^{* * *} \\
(0.00)\end{array}$ & $\begin{array}{c}-0.0153^{* * *} \\
(0.00)\end{array}$ & $\begin{array}{c}-0.0173^{* * *} \\
(0.00)\end{array}$ & $\begin{array}{c}-0.0180^{* * *} \\
(0.00)\end{array}$ & $\begin{array}{c}-0.0168^{* * *} \\
(0.00)\end{array}$ \\
\hline Dividend Yield & $\begin{array}{c}0.8278 * * * \\
\quad(0.06)\end{array}$ & & & & \\
\hline Z-score & & $\begin{array}{c}-0.0001^{* * * *} \\
(0.00)\end{array}$ & & & \\
\hline Market Leverage $^{2}$ & & & $\begin{array}{c}0.0302 \\
(0.04)\end{array}$ & & \\
\hline Constant & $\begin{array}{c}0.0076 \\
(0.01)\end{array}$ & $\begin{array}{c}0.0373 * * * \\
(0.01)\end{array}$ & $\begin{array}{c}0.0335 * * * \\
(0.01)\end{array}$ & $\begin{array}{c}0.0349 \\
(0.03)\end{array}$ & $\begin{array}{c}0.1390 * * * \\
(0.05)\end{array}$ \\
\hline Observations & 63,864 & 56,451 & 63,959 & 63,959 & 63,959 \\
\hline SIC 2digit Fixed Effects & No & No & No & Yes & Yes \\
\hline Year Fixed Effects & No & No & No & No & Yes \\
\hline
\end{tabular}

Table 7

The table presents robustness tests for the sample firms estimated as a pooled OLS regression over the period 1962-2013. Variable definitions and specification follow the main regressions. In Column (1), (2) and (3), we control for dividend yield, Altman's Z-score, and market leverage squared, respectively. In Columns (4) and (5), we additionally control for industry and year fixed effects. Robust standard errors, clustered by firm, are shown in parentheses. Predicted signs for the main variables of interest are also shown in parentheses. Significance is indicated as follows: ${ }^{* * *} \mathrm{p}<0.01,{ }^{* *} \mathrm{p}<0.05,{ }^{*} \mathrm{p}<0.10$. 
Results for systematic and idiosyncratic future earnings growth volatility with alternative measures

(1)

(2)

Dependent variable: Firm returns $t+1$

Systematic EGVOL Median Dispersion

\begin{tabular}{|c|c|c|}
\hline & (from VIO) & (analyst forecasts) \\
\hline Systematic EGVOL (-) & $\begin{array}{l}-1.9274^{* * * *} \\
(0.04)\end{array}$ & $\begin{array}{c}-0.0138 \\
(0.04)\end{array}$ \\
\hline Systematic EGVOL x Low Growth Dummy (-) & $\begin{array}{l}0.0701 * * * \\
(0.01)\end{array}$ & $\begin{array}{c}-0.0015 \\
(0.03)\end{array}$ \\
\hline Idiosyncratic EGVOL (-) & $\begin{array}{c}-0.0014 \\
(0.00)\end{array}$ & $\begin{array}{l}-0.2684^{* * *} \\
(0.08)\end{array}$ \\
\hline Idiosyncratic EGVOL x Low Growth Dummy (-) & $\begin{array}{l}-0.0080^{*} \\
(0.00)\end{array}$ & $\begin{array}{c}0.0667 \\
(0.08)\end{array}$ \\
\hline Market Leverage & $\begin{array}{l}0.0929 * * * \\
(0.01)\end{array}$ & $\begin{array}{c}0.1361 * * * \\
(0.02)\end{array}$ \\
\hline Earnings-to-price Ratio & $\begin{array}{l}-0.0429 * * * \\
(0.01)\end{array}$ & $\begin{array}{c}-0.0329 \\
(0.03)\end{array}$ \\
\hline Book-to-market equity & $\begin{array}{l}0.0024^{* * *} \\
(0.00)\end{array}$ & $\begin{array}{l}0.0235^{* * *} \\
(0.00)\end{array}$ \\
\hline Asset Beta & $\begin{array}{l}0.0190^{* * *} \\
(0.01)\end{array}$ & $\begin{array}{l}0.0264 * * * \\
(0.01)\end{array}$ \\
\hline ACCRUALS & $\begin{array}{l}-0.0811^{* *} \\
(0.03)\end{array}$ & $\begin{array}{c}-0.0333 \\
(0.05)\end{array}$ \\
\hline Capital Expenditure & $\begin{array}{l}-0.0209 \\
(0.02)\end{array}$ & $\begin{array}{l}-0.2686^{* *} \\
(0.12)\end{array}$ \\
\hline Net Operating Assets & $\begin{array}{c}0.0317^{* * *} \\
(0.01)\end{array}$ & $\begin{array}{c}0.0342^{* *} \\
(0.02)\end{array}$ \\
\hline Issuance & $\begin{array}{c}-0.0997 * * * \\
(0.01)\end{array}$ & $\begin{array}{c}-0.0901^{* * *} * \\
(0.02)\end{array}$ \\
\hline Asset Growth & $\begin{array}{c}-0.0870^{* * *} \\
(0.01)\end{array}$ & $\begin{array}{c}-0.1000^{* * *} \\
(0.02)\end{array}$ \\
\hline Lag of Asset Growth & $\begin{array}{c}-0.0017 \\
(0.01)\end{array}$ & $\begin{array}{c}-0.0232^{*} \\
(0.01)\end{array}$ \\
\hline Market Value (Bil) & $\begin{array}{c}0.0003 \\
(0.00)\end{array}$ & $\begin{array}{c}-0.0007 \\
(0.00)\end{array}$ \\
\hline 6-month BHRET & $\begin{array}{c}0.0247^{* * *} \\
(0.01)\end{array}$ & $\begin{array}{c}0.0065 \\
(0.01)\end{array}$ \\
\hline 36-month BHRET & $\begin{array}{c}-0.0252^{* * *} \\
(0.00)\end{array}$ & $\begin{array}{c}-0.0203^{* * *} \\
(0.00)\end{array}$ \\
\hline Constant & $\begin{array}{c}2.4197^{* * *} * \\
(0.06)\end{array}$ & $\begin{array}{c}0.0514 \\
(0.04)\end{array}$ \\
\hline Observations & 43,374 & 19,422 \\
\hline
\end{tabular}

